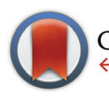

CrossMark

Cite this: Dalton Trans., 2016, 45 7605

Received 15th December 2015, Accepted 20th March 2016

DOI: $10.1039 / c 5 d t 04888 \mathrm{e}$

www.rsc.org/dalton

\section{Synthesis of oxime-based CO-releasing molecules, CORMs and their immobilization on maghemite nanoparticles for magnetic-field induced $\mathrm{CO}$ release $\uparrow$}

\author{
Hajo Meyer, ${ }^{a}$ Markus Brenner, ${ }^{a}$ Simon-P. Höfert, ${ }^{a}$ Tim-O. Knedel, ${ }^{a}$ Peter C. Kunz, ${ }^{a}$ \\ Annette M. Schmidt, ${ }^{b}$ Alexandra Hamacher, ${ }^{c}$ Matthias U. Kassack ${ }^{c}$ and \\ Christoph Janiak*a
}

\begin{abstract}
Oxime-based CO-releasing molecules (oximeCORMs) were immobilized with a catechol-modified backbone on maghemite iron oxide nanoparticles (IONPs) to give oximeCORM@IONP. The CO release from the free and immobilized oximeCORMs was measured using the standard myoglobin assay. The oximeCORM-nanoparticles were coated with dextran for improved water solubility and confined into an alginate shell for protection and separation from the surrounding myoglobin assay to allow for CO release studies by UV/Vis absorption without interference from highly-absorptive oximeCORM@IONP. Half-lifes of the oxime-based polymer-confined alginate@dextran@oximeCORM@IONPs were estimated at $20{ }^{\circ} \mathrm{C}$ to 814 $\pm 23 \mathrm{~min}$, at $37^{\circ} \mathrm{C}$ to $346 \pm 83 \mathrm{~min}$ and at $50^{\circ} \mathrm{C}$ to $73 \pm 1 \mathrm{~min}$. The alginateadextran@oximeCORM@IONP composite showed a further decrease of the half-life of $\mathrm{CO}$ release to $153 \pm 27 \mathrm{~min}$ at $37^{\circ} \mathrm{C}$ through local magnetic heating of the susceptible iron oxide nanoparticles with application of an external alternating magnetic field (31.7 kA m $, 247 \mathrm{kHz}, 39.9 \mathrm{mTesla)}$. The activation energy for the CO release from molecular dicarbonylchlorido(imidazole-2-carbaldehydeoxime)(alkoxycarbonyl)ruthenium(॥) complexes is determined to be $\sim 100 \mathrm{~kJ} \mathrm{~mol}^{-1}$ for five different imidazole-oxime derivatives.
\end{abstract}

\section{Introduction}

The toxic physiological effects of carbon monoxide (CO) were first described by John Haldane in $1927 .{ }^{1} \mathrm{CO}$ is generally known as a highly toxic gas which hinders the oxygen transport in the blood system, by strong coordination to the oxygen binding site in hemoglobin. Even breathing of small quantities (about $100 \mathrm{ppm}$ in air) of this color- and odorless gas can be potentially harmful to the human organism. ${ }^{2,3}$ On the other hand, carbon monoxide is classified as a biochemical messenger molecule like hydrogen sulfide and nitrogen oxide. ${ }^{4-6}$ Human organisms express heme oxygenase enzymes, ${ }^{7}$ which are capable of producing carbon monoxide continuously in

\footnotetext{
${ }^{a}$ Institut für Anorganische Chemie und Strukturchemie, Universität Düsseldorf, 40204 Düsseldorf, Germany. E-mail: janiak@uni-duesseldorf.de

${ }^{b}$ Institut für Physikalische Chemie, Universität zu Köln, Luxemburger Str. 116, D-50939 Köln, Germany. E-mail: annette.schmidt@uni-koeln.de

${ }^{c}$ Institut für Pharmazeutische und Medizinische Chemie, Universität Düsseldorf, 40204 Düsseldorf, Germany. E-mail: matthias.kassack@hhu.de

$\dagger$ Electronic supplementary information (ESI) available: Synthesis for oximebased CORMs, NMR, IR and ESI-mass spectra, myoglobin assay, leaching experiments, DLS experiments, TEM measurements, toxicity tests, and activation energy. See DOI: 10.1039/c5dt04888e
}

order to regulate the circadian rhythms, memory and hemodynamics. ${ }^{8-10}$ Due to its regulatory and cytoprotective effects $\mathrm{CO}$ has already been extensively investigated for medical applications. ${ }^{9}$ Yet, when $\mathrm{CO}$ is administered to a human organism as a gas, it is difficult to accumulate at a specific site (e.g. tumor or burned skin). Gaseous CO as a therapeutic agent features a half-life of 3 to 7 hours in the body and was well tolerated at $3 \mathrm{mg}$ per $\mathrm{kg}$ for one hour. CO binds reversibly to cellular targets and the only way for CO to exit mammal bodies in a therapeutic approach was by lung exhalation. ${ }^{11,12}$ In fact the gas also reaches healthy tissue and the dose needs to be relatively high in order to achieve an effect on the desired tissue. In addition, the quantity needs to be carefully controlled and special administering equipment is necessary.

CO releasing molecules (CORMs), primarily metal carbonyl derivatives were invented for specific targeting and controlled release of carbon monoxide. Metal carbonyl derivatives are investigated also as antibacterial compounds and for their anticancer therapeutic potential. ${ }^{13}$ However, the first CORMs were hardly water-soluble and released $\mathrm{CO}$ a way too fast for precise administering (half the gas load in less than one minute under physiological conditions). ${ }^{14}$ Motterlini and co- 
workers $^{3,15}$ introduced in 2003 the water-soluble complex $\left[\mathrm{Ru}(\mathrm{CO})_{3}\right.$ (glycinate) (CORM-3) which released $\mathrm{CO}$ under physiological conditions ${ }^{16}$ and showed vasodilatative, antiinflammatory, renoprotective and anti-apoptosis effects in preclinical studies. ${ }^{17}$ Since the last decade, Ru-based CORMs have become a very important field of research with several studies of CORM-2 and the water-soluble CORM-3 (Scheme 1). ${ }^{9,14,16}$

The half-life of CO release from CORM-3 via a pseudo-firstorder reaction is $1 \mathrm{~min}$ at $37{ }^{\circ} \mathrm{C}$ in PBS buffer, ${ }^{18} 2.3 \mathrm{~min}$ at $30{ }^{\circ} \mathrm{C}$ in PBS buffer ${ }^{19}$ and 3.6 min in human plasma, ${ }^{20}$ apparently due to CO-abstraction by heme proteins. ${ }^{21}$ Recent studies presented CORMs which liberate CO upon external stimuli like change in the $\mathrm{pH}^{22,23}$ increasing temperature, UV irradiation $^{24,25}$ and oxidative or enzymatic degradation. ${ }^{26,27}$ The immobilization of CORMs in ${ }^{28}$ and on ${ }^{29,30}$ other materials opens new methodologies in medicinal chemistry. ${ }^{31,32}$ However, different possible medical applications of CORMs will require CORMs with different release kinetics.

Drugs which are conjugated to polymers are restricted to the vascular system and can be transported directly to the target area. A passive accumulation of macromolecular systems in tumor tissues due to the so-called enhanced permeability and retention (EPR) effect was first described and investigated by Maeda et al. ${ }^{33,34}$

The growth of tumors ( $>2 \mathrm{~mm}$ ) is ensured by fast growing blood vessels to supply nutrients and dioxygen. The blood vessels are destabilized due to vascular endothelial growth factors (VEGFs) into the extracellular space and have higher permeability than normal grown blood vessels. ${ }^{35}$ The resulting blood vessels lack tight junctions that are normally present between adjacent vascular endothelial cells. This deficiency leaves holes on an order of magnitude greater than normal vascular pores (healthy tissue has pores of 5 to $8 \mathrm{~nm}$, tumor tissue can have pores of about $50 \mathrm{~nm}$ and inter-endothelial junctions of about $500 \mathrm{~nm}$ ). The EPR effect refers to the pro-
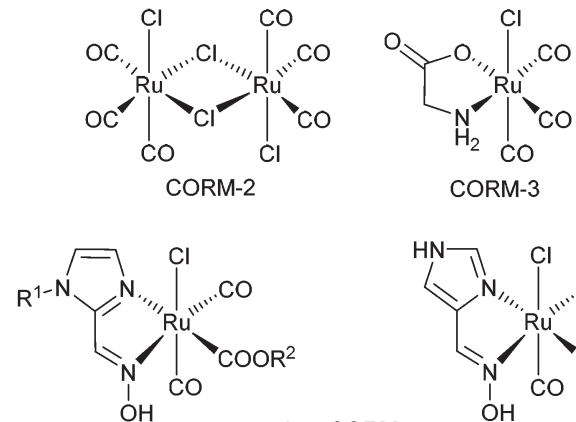

oxime CORMs

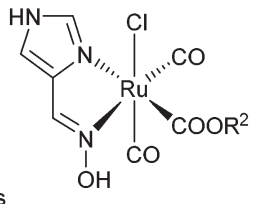

$$
\begin{aligned}
& \text { 1a: } R^{1}=H, R^{2}=M e, \quad t_{1 / 2}=60 \mathrm{~min} \\
& \text { 2a: } R^{1}=H, R^{2}=E t, \quad t_{1 / 2}=70 \mathrm{~min} \\
& \text { 1b: } R^{1}=M e, R^{2}=M e, t_{1 / 2}=40 \mathrm{~min} \\
& \text { 2b: } R^{1}=M e, R^{2}=E t, t_{1 / 2}=60 \mathrm{~min}
\end{aligned}
$$

Scheme 1 Scheme of the synthesized oxime-based CORMs from Oresmaa et al. with their half-lifes. The half-lifes were determined at ambient (room) temperature in a phosphate buffered saline solution $(\mathrm{pH}=6.8)$. $^{38}$ perties of these large pores to allow polymers to enter the tumor interstitium and to remain and accumulate there because the polymers are not removed by the lymphatic system. ${ }^{36}$

The accumulation of functionalized polymers in tumor tissue with the ability to release $\mathrm{CO}$ is an additional concept of developing polymer-CORM conjugates. In such conjugates the use of a slow $\mathrm{CO}$ releaser from which the $\mathrm{CO}$ release can be triggered or activated by magnetic heating through alternating magnetic field should be of interest.

Different CORMs with ruthenium carbonyls are known and the number is still increasing. ${ }^{37}$ Oresmaa et al. described a simple synthetic route to oxime-based CORMs for which they reported a longer half-life for $\mathrm{CO}$ release than for CORM-3 ${ }^{38}$ (Scheme 1).

In our previous work, we presented a new concept of controlled CO release by covalently attaching the CO-releasing molecule (a CORM-3 analogue) to the surface of iron oxide nanoparticles which are susceptible to local heating through an external alternating current magnetic field. ${ }^{39}$ The increased temperature of the nanoparticles, due to the external alternating magnetic field, decreased the half-life from $13 \pm 2$ min to $7 \pm 2 \mathrm{~min}$ in a buffered myoglobin-assay solution kept at $25^{\circ} \mathrm{C}$.

Here we target the covalent immobilization of relatively stable (long half-life) oxime-based CORMs on the surface of iron oxide nanoparticles. In addition a dextran coating is applied for better water solubility and as a barrier against heme proteins.

At the same time the strong absorptivity of the black IONP dispersion hampers CO release studies with the standard myoglobin assay in the same dispersion. The CO release by a myoglobin assay is followed by UV/Vis spectrometry. Therefore, we used an alginate confinement of "water-soluble" dextran@ oximeCORM@IONP to achieve a spatial separation from the surrounding myoglobin assay.

\section{Results and discussion}

\section{Synthesis}

The covalent immobilization of the oxime-based CORMs on an iron oxide nanoparticle (IONP) surface is depicted in Scheme 2 .

Starting with the commercially available 2-chloro-3', $4^{\prime}$-dihydroxyacetophenone 3 (Scheme 3), we first tried unsuccessfully a simple condensation reaction with $1 \mathrm{H}$-imidazole2-carbaldehyde 4 to try to obtain the condensation product

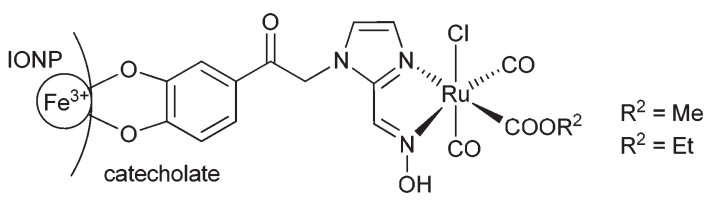

Scheme 2 Covalent immobilization of oxime-based CORM on an iron oxide nanoparticle (IONP) surface through a catecholate group. 
<smiles>O=C(CCl)c1ccc(O)c(O)c1</smiles><smiles>CCCCC(C)(C)C</smiles><smiles>CC(C)CCCCC(C)(C)C</smiles>

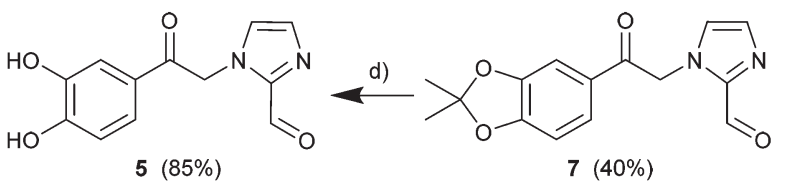<smiles>[AlH2][AlH2]</smiles>

e) $\downarrow$<smiles>CC(C)CC(=O)c1ccc(O)c(O)c1</smiles><smiles>CC1(C)Oc2ccc(C(=O)Cn3ccnc3/C=N/O)cc2O1</smiles>

Scheme 3 Synthetic route (with yields) for the coupling of the catechol group with $1 \mathrm{H}$-imidazol-2-carbaldehyde (4) to 1-(2-(3,4-dihydroxyphenyl)-2-oxoethyl)- $1 \mathrm{H}$-imidazole-2-carbaldehyde (5) and the acetate protected (8) and unprotected oxime (9). (a) Acetonitrile, sodium carbonate, $60^{\circ} \mathrm{C}, 5 \mathrm{~d}$; (b) dry toluene, dry acetone, phosphorus pentoxide, $75^{\circ} \mathrm{C}, 4 \mathrm{~h}$; (c) acetonitrile, sodium carbonate, $60{ }^{\circ} \mathrm{C}, 7 \mathrm{~d}$; (d) acetic acid, hydrochloric acid, $100{ }^{\circ} \mathrm{C}, 2 \mathrm{~h}$; (e) sodium carbonate, hydroxylammonium chloride, $70^{\circ} \mathrm{C}, 24 \mathrm{~h}$.

1-(2-(3,4-dihydroxyphenyl)-2-oxoethyl)-1H-imidazole-2-carbaldehyde 5 in a single step. The single-step route failed so that the diol was first protected by an acetal group to form product 6 in good yields. The condensation of 6 with 4 to give 1-(2-(3,4-dihydroxyphenyl)-2-oxoethyl)-1 $H$-imidazole-2-carbaldehyde 7 in acetonitrile with an equimolar ratio of a base proved successful. Acid cleavage of the acetal protecting group afforded the desired product 1-(2-(3,4-dihydroxyphenyl)-2-oxoethyl)-1Himidazole-2-carbaldehyde $\mathbf{5}$ in high yields. Introducing the oxime function into compounds 7 and $\mathbf{5}$ was done similarly to ref. 38 (Scheme 3). The reaction times were extended up to $24 \mathrm{~h}$ to obtain good yields for $(E)-1-(2-(2,2-$ dimethylbenzo[d][1,3]dioxol-5-yl)-2-oxoethyl)-1 $H$-imidazol-2-carbaldehyde-oxime 8 (75\%) and 1-(2-(3,4-dihydroxyphenyl)-2-oxoethyl)-1H-imidazole-2-carbaldehyde-oxime 9 (47\%).

The synthesis of the diol-protected ruthenium carbonyl oximes $\mathbf{1 0}$ and $\mathbf{1 1}$ was performed as described in the literature $^{38}$ with $\left[\mathrm{Ru}(\mathrm{CO})_{3} \mathrm{Cl}_{2}\right]_{2}(12)$ and an extended reaction time of $5 \mathrm{~d}$ (Scheme 4). To obtain the methoxy-compound 10 the reaction was carried out in methanol and for the ethoxy-compound $\mathbf{1 1}$ in ethanol. CORMs $\mathbf{1 0}$ and $\mathbf{1 1}$ precipitated from the solution as the modified backbone leads to lower solubility in polar solvents than for the parent compounds $\mathbf{a}$ and $\mathbf{b}$ (Scheme 1).

For immobilization on an iron oxide nanoparticle surface the dihydroxyphenyl-oxime 9 was reacted with $\left[\mathrm{Ru}(\mathrm{CO})_{3} \mathrm{Cl}_{2}\right]_{2}$ (12) to give the ruthenium carbonyl oximes $\mathbf{1 3}$ and $\mathbf{1 4}$ as shown in Scheme 5.

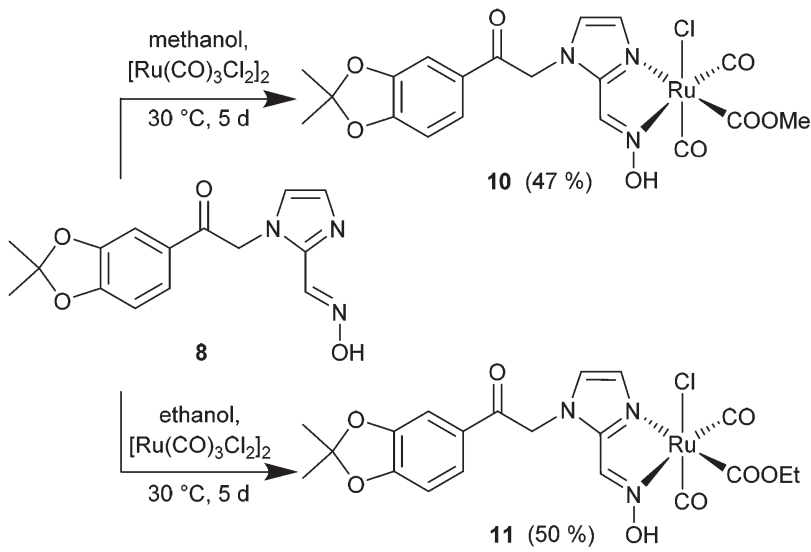

Scheme 4 Synthesis of CORMs with the diol-protected catechol oxime 8 as methoxy- (10) and ethoxy- (11) ruthenium complexes (yields in parentheses).

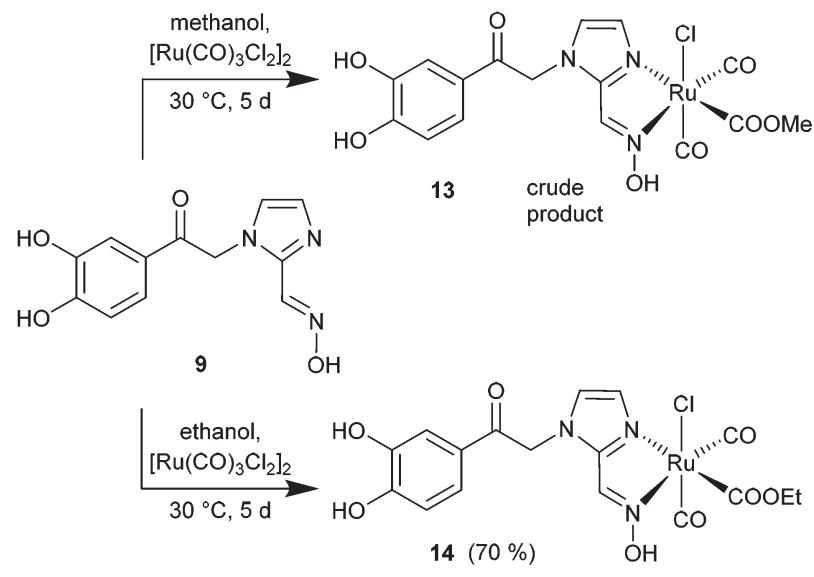

Scheme 5 Synthesis of CORMs with the (unprotected) catechol oxime 9 as methoxy- (13) and ethoxy- (14) ruthenium complexes (yields in parentheses).

Electron spray ionization mass spectrometric analysis of 10-14 in acetonitrile solution showed ligand lability (see Fig. S3, ESI $\dagger$ ). For compounds 10 and 11 or 13 and 14, respectively, identical mass spectra were obtained and the isotopic pattern showed a ruthenium complex from which the methoxy (or ethoxy) group $\left(\mathrm{OR}^{-}\right)$, a $\mathrm{CO}$ unit and/or a chloride ligand had been lost. In addition, a proton was abstracted, presumably from the $\mathrm{N}-\mathrm{OH}$ group, which together with $\mathrm{CO}$ and $\mathrm{OR}^{-}$amounts to the liberation of formic acid ester or with $\mathrm{OR}^{-}$ only to the liberation of the alcohol $\mathrm{ROH}$. Instead, acetonitrile was coordinated under ESI-MS conditions. Hence, the dominant fragments (for ${ }^{102} \mathrm{Ru}$ ) of $m / z=499.1(\mathbf{1 0}, \mathbf{1 1})$ or 459.2 (13, 14) correspond to $\left[\mathrm{M}-\mathrm{OR}^{-}-\mathrm{CO}-\mathrm{Cl}^{-}-\mathrm{H}^{+}+\mathrm{CH}_{3} \mathrm{CN}\right]^{+}$and $m / z=527.0(\mathbf{1 0}, \mathbf{1 1})$ or $487.0(\mathbf{1 3}, \mathbf{1 4})$ to $\left[\mathrm{M}-\mathrm{OR}^{-}-\mathrm{Cl}^{-}-\mathrm{H}^{+}+\right.$ $\left.\mathrm{CH}_{3} \mathrm{CN}\right]^{+}(\mathrm{R}=\mathrm{Me}, \mathrm{Et})$. The lability of carbonyl complexes in ESI mass spectrometric analysis is known. ${ }^{40}$

IR spectroscopic measurements of 10-14 show the expected strong carbonyl absorptions (Fig. S1 in the ESI $\dagger$ ) which agree 
Table 1 Carbonyl stretching frequencies of oxime ruthenium CORMs ${ }^{a}$

\begin{tabular}{llll}
\hline Compound & $\nu \mathrm{CO}\left[\mathrm{cm}^{-1}\right]$ & $\nu \mathrm{CO}\left[\mathrm{cm}^{-1}\right]$ & Ref. $^{d}$ \\
\hline $\mathbf{1 a}^{a, c}$ & 2064 & 1990 & Fig. S2-1a \\
$\mathbf{2 a} \mathbf{a}^{a, c}$ & 2067 & 1994 & Fig. S2-1a \\
$\mathbf{1 a}^{b, c}, \mathbf{2 a}{ }^{b, c}$ & $2056-2059$ & $1980-1985$ & 38 \\
$\mathbf{1 0}^{a}$ & 2075 & 1989 & Fig. S2-1b \\
$\mathbf{1 1}^{a}$ & 2065 & 1988 & Fig. S2-1b \\
$\mathbf{1 4}^{a}$ & 2077 & 2012 & Fig. S2-2 \\
$\mathbf{1 7}^{a}$ & 2064 & $1995,1961^{e}$ & Fig. S2-3 \\
$\mathbf{1 8}^{a}$ & 2061 & 1991 & Fig. S24 \\
$\mathbf{1 8}^{a}$ after CO release & 2071,2015 & 1992 & Fig. S24
\end{tabular}

${ }^{a} \mathrm{KBr}$ disks. ${ }^{b}$ FT-IR in DMSO. ${ }^{c}$ Formula in Scheme $1 .{ }^{d}$ This work with reference to the figure showing the IR spectrum, unless indicated otherwise. ${ }^{e}$ We trace the third $\mathrm{CO}$ band to partial $\mathrm{CO}$ release during CORM deposition on IONP and inclusion in dextran in water (cf. Scheme 6).

well with the ones reported by Oresmaa et $a{ }^{38}$ for $\mathbf{a}$ and $\mathbf{b}$ in the regions 2056-2059 $\mathrm{cm}^{-1}$ and 1980-1985 $\mathrm{cm}^{-1}$ (Table 1).

Maghemite nanoparticles (15) were synthesized by the known method from Ewijk et al. ${ }^{41} \mathrm{~A}$ catechol based anchor group is common for immobilizing molecules on an IONP surface. $^{42}$ The unprotected catechol-oxime ruthenium complex 14 was immobilized on the surface of maghemite nanoparticles. Compound $\mathbf{1 4}$ was dissolved in water under basic conditions and stirred with maghemite nanoparticles. To prevent agglomeration of the nanoparticles the combined solutions of both compounds were kept below pH 8. After precipitation with acetone and washing with ethanol, the oximeCORM@IONP composite nanoparticles 16 were not able to build a stable dispersion in MOPS-buffer or water but sedimented within a few seconds (see the ESI $\uparrow$ for DLS and TEM analysis of 16). To increase the solubility of the oximeCORM@IONP nanoparticles in water, they were coated by using dextran polymers to give dextran@oximeCORM@IONP (17). Water-soluble dextran $\left(M=500000 \mathrm{~g} \mathrm{~mol}^{-1}\right)$ consists of glucose monomers with $\alpha-1,4$ - and $\alpha-1,6$-connectivity and was added during the reaction of $\mathbf{1 4}$ with the iron oxide nanoparticles.
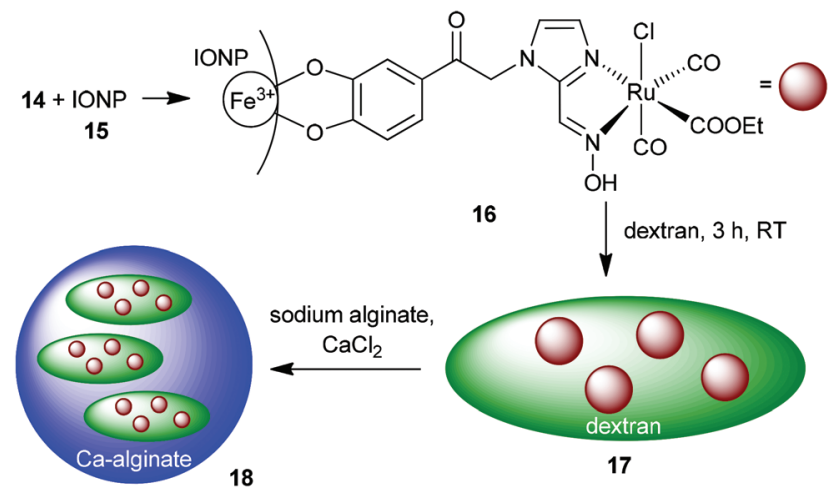

Scheme 6 Synthesis of the composite material alginateadextrane oximeCORMaIONP (18) by immobilization of the oximeCORM 14 on the maghemite nanoparticle surface 15.
The IR spectrum of the composite material 17 (Fig. S4 in the ESI $\dagger$ ) shows the OH-vibrations of the dextran at $3600-3000 \mathrm{~cm}^{-1}$ and the carbonyl region exhibits three strong absorptions at 2064, 1995 and $1961 \mathrm{~cm}^{-1}$.

The amount of ruthenium in the dextran@oximeCORM@IONP (17) composite was determined by atomic absorption spectroscopy (AAS) to an average of $0.60 \mathrm{wt} \%$ ruthenium and a molar $\mathrm{Ru}: \mathrm{Fe}$ ratio of 1:25 (see Experimental section or the ESI $\dagger$ for details). This is the same molar $\mathrm{Ru}: \mathrm{Fe}$ ratio as in our previous report on a CORM-3 analog on IONP $\left(\mathrm{Ru}:\right.$ Fe $\left.1: 25^{39}\right)$.

Further, composite 17 was incorporated into calcium alginate spheres. A mixture of $\mathbf{1 7}$ with sodium alginate was added dropwise to a calcium chloride solution. Calcium cross-linked alginate spheres were rapidly formed which almost quantitatively incorporate the dextran@oximeCORM@IONP substrate as is evident from the clear, non-colored surrounding solution (Fig. S26 in the ESI $\dagger$ ). The IR spectrum of the composite material 18 (Fig. S28 in the ESI†) shows two strong absorptions at 2061 and $1991 \mathrm{~cm}^{-1}$, which are indicators for the immobilized carbonyls on the nanoparticle surface. Yet, the still necessary use of water to anchor 14 on IONPs to give 16 and in the dextran and alginate coating of 16 to 17 and further to 18 represents a drawback and already induces partial decomposition with a loss of CO (see below and Table S1 in the ESI $\dagger$ ). Future work has to address replacing water by other solvents.

\section{CO release}

The half-lifes $t_{1 / 2}$ of the CO release from compounds 1, 2, 10, 11 and 18 were measured using the myoglobin assay to elucidate differences in the $\mathrm{CO}$ release kinetics at 20,37 and $50{ }^{\circ} \mathrm{C}$ (Fig. 1a). A 3-(N-morpholino)propanesulfonic acid buffer
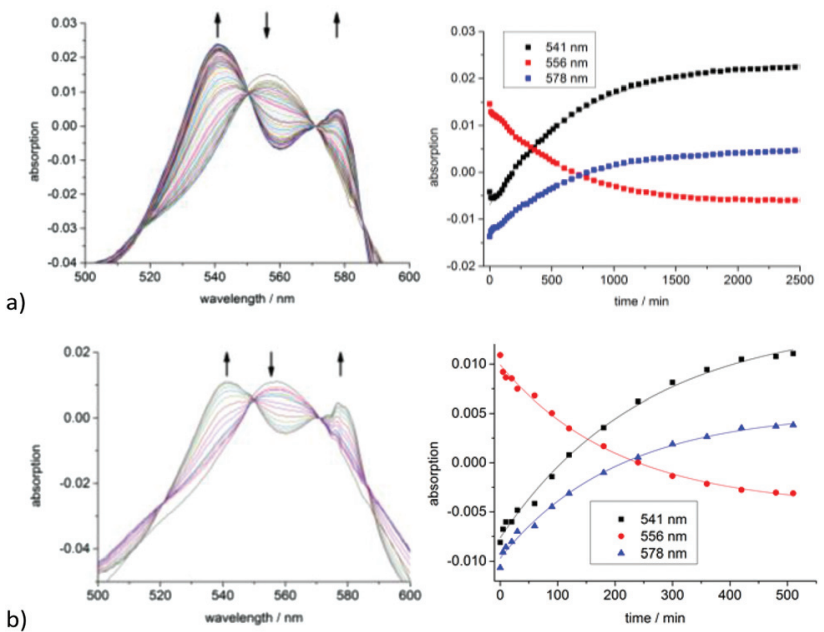

Fig. 1 Time-dependent visible absorption spectra (left) and the plot of the intensity changes of selected wavelengths (right) of alginatea dextranaoximeCORMaIONP (18) with the myoglobin assay at $37^{\circ} \mathrm{C}$ (a) without the influence of an external alternating magnetic (AC) field to $t_{1 / 2}=346 \pm 83 \mathrm{~min}$, and (b) with alternating field $t_{1 / 2}=155 \pm 27 \mathrm{~min}$. Arrows in the absorption spectra mark the selected wavelengths with the direction of their time-dependent change. 
( $\mathrm{pH}=7.4,0.1 \mathrm{M}$ ) was used by us instead of the phosphate buffer which Oresmaa et al. described to prevent further agglomeration of the IONP-containing samples and to make the results comparable to our previously presented system. ${ }^{39}$ All measurements were done three times to ensure reproducibility.

The half-lifes of the $\mathrm{CO}$ release are listed in Table 2 (for kinetic data see Fig. S5-S25 in the ESI†). Oresmaa et al. described a slightly faster CO release from the methoxy-1a $\left(t_{1 / 2}=60 \mathrm{~min}\right)$ than from the ethoxy-2a oximeCORM (cf. Scheme 1) $\left(t_{1 / 2}=70 \mathrm{~min}\right)$ at ambient temperature, albeit not further specified temperature. ${ }^{38}$ From our thermostated measurement at $20^{\circ} \mathrm{C}, 37^{\circ} \mathrm{C}$ and $50{ }^{\circ} \mathrm{C}$, the methoxy- (1a) and ethoxy- (2a) derivatives have the same half-life within the experimental error. We note that the oximeCORM compounds 1a and 2a show a slower CO release than CORM-3 at $37{ }^{\circ} \mathrm{C}$ $\left(t_{1 / 2} \leq 1 \mathrm{~min}\right)$ in the presence of the myoglobin assay.

The diol-protected catechol oximeCORMs 10, 11 and the unprotected catechol oximeCORM 14 also show similar halflifes within the experimental error with a slightly faster release than from $1 \mathrm{a}$ and $2 \mathrm{a}$ at $20^{\circ} \mathrm{C}$, which might correlate to the modified backbone.

The dark "soluble" dextran-coated iron oxide nanoparticles 17 do not lend themselves to follow the CO release with the myoglobin assay due to their strong UV/Vis absorption. ${ }^{42}$ Dextran coating leads to a stable dispersion with no sedimentation anymore. Thus, the high background absorption from the dark color from the iron oxide nanoparticles masks the absorption changes of the myoglobin assay. The confinement of dextran@oximeCORM@IONP in calcium alginate spheres allowed for minimization of the spectral interference by separation within the myoglobin assay. ${ }^{42}$ We briefly note that there are other methods available for $\mathrm{CO}$ release studies from CORMs. Electrochemical sensing, ${ }^{43}$ fluorescent probes, ${ }^{44,45}$ gas-phase IR spectroscopy, ${ }^{43}$ or gas chromatography ${ }^{46,47}$ have been reported in the literature. Yet, the inexpensive and easy

Table 2 Half-lifes of the CO release from oximeCORMs determined using the myoglobin assay at different temperatures

\begin{tabular}{|c|c|c|c|c|}
\hline \multirow[b]{2}{*}{ Compound } & \multicolumn{4}{|l|}{$t_{1 / 2}[\mathrm{~min}]$} \\
\hline & $20^{\circ} \mathrm{C}$ & $\sim 25^{\circ} \mathrm{C}$ & $37^{\circ} \mathrm{C}$ & $50^{\circ} \mathrm{C}$ \\
\hline $\begin{array}{l}\mathbf{1 a} \\
\mathbf{1 \mathbf { a } ^ { a }}\end{array}$ & $220 \pm 23$ & 60 & $21 \pm 2$ & $5 \pm 1$ \\
\hline $\begin{array}{l}2 \mathbf{a} \\
2 \mathbf{a}^{a}\end{array}$ & $226 \pm 9$ & 70 & $18 \pm 1$ & $6 \pm$ \\
\hline 10 & $172 \pm 23$ & & $18 \pm 3$ & $4 \pm$ \\
\hline 11 & $155 \pm 13$ & & $18 \pm 1$ & $4 \pm 1$ \\
\hline 14 & $207 \pm 6$ & & $16 \pm 1$ & $3 \pm 1$ \\
\hline $\begin{array}{l}18 \\
18 \text { in AC field }\end{array}$ & $814 \pm 23$ & & $\begin{array}{l}346 \pm 83 \\
153+27\end{array}$ & $73 \pm 1$ \\
\hline
\end{tabular}

${ }^{a}$ The work of Oresmaa et $a l^{38}$ does not specify a temperature. Thus, ambient or room temperature can be assumed which can be depending on season, climate and weather - somewhere between $15^{\circ} \mathrm{C}$ to $30{ }^{\circ} \mathrm{C}$. The half-life values from Oresmaa et al. must be traced to a temperature higher than $20{ }^{\circ} \mathrm{C}$ or to buffer influences. ${ }^{b}$ With applied alternating magnetic field $\left(31.7 \mathrm{kA} \mathrm{m}^{-1}, 247 \mathrm{kHz}\right.$, 39.9 mTesla). alginate-separation method allows for working with the widely accepted myoglobin assay.

The calcium alginate shell around the "soluble" dextrancoated iron oxide nanoparticles presents a membrane, which allows for diffusion of gaseous CO but prevents the interaction with the outside protein and sodium dithionite of the myoglobin assay. ${ }^{42}$

Previous CO-release studies from CORM-2 and CORM-3 showed that the rate depended on myoglobin and was accelerated by an increasing concentration of the reducing agent, sodium dithionite. ${ }^{21}$ The loss of carbon monoxide was shown when CORM-3 was preincubated with sodium dithionite in the absence of myoglobin. After reduction of the myoglobin and removal of the sodium dithionite in the assay, no liberation of CO from CORM-3 was seen. ${ }^{19}$ The interactions of CORM-3 with proteins result in the loss of a chloride ion, glycinate, and one $\mathrm{CO}$ ligand because of rapid formation of stable protein-Ru $\left(\mathrm{CO}_{2}\right)$ adducts. $^{21}$

For the oxime-based CORMs $(\mathbf{1}, \mathbf{2})$ Oresmaa suggested "that the alkoxycarbonyl group plays an important role in CO release. Whether the role is merely to destabilize carbonyl ligands or act as a source of CO remains to be studied". ${ }^{38}$

Furthermore, the alginate spheres containing the iron oxide nanoparticles were magnetic and could be retained at the bottom of the cuvette with a magnet to prevent them from moving into the light path during UV/Vis measurement (Fig. S22 in the ESI $\dagger$ ). Spheres of the composite material 18 were transferred within $30 \mathrm{~min}$ after their synthesis into the cuvette under nitrogen to avoid contamination with dioxygen. MOPS-buffer and myoglobin solution (containing $\mathrm{Na}_{2} \mathrm{~S}_{2} \mathrm{O}_{3}$ ) were added and the $\mathrm{CO}$ release measurements were started immediately by collecting time-dependent UV/Vis spectra at 20, 37 and $50{ }^{\circ} \mathrm{C}$. The half-lifes were determined from the kinetic curves of the absorption changes with time (see the ESI $\dagger$ ) and are listed in Table 2.

The CO release of the composite material $\mathbf{1 8}$ was also measured at $37{ }^{\circ} \mathrm{C}$ (surrounding solution temperature) under the influence of an external alternating magnetic (AC) field

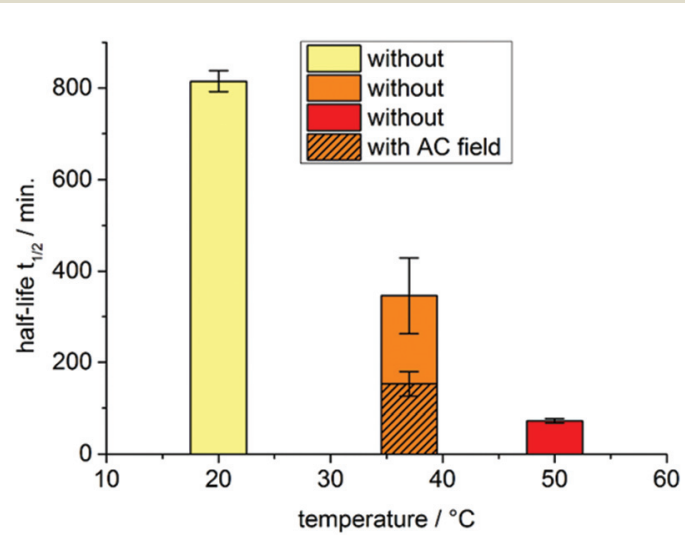

Fig. 2 Half-lifes for temperature-dependent $\mathrm{CO}$ release from alginate@ dextran@oximeCORM@IONP (18) without and with applied alternating (AC) magnetic field (at $37^{\circ} \mathrm{C}$ only). 
(31.7 $\mathrm{kA} \mathrm{m}^{-1}, 247 \mathrm{kHz}, 39.9$ mTesla) to determine the accelerated $\mathrm{CO}$ release due to magnetic heating of the iron oxide particles (Fig. 2). The estimated half-life at $37^{\circ} \mathrm{C}$ with an $\mathrm{AC}$ field is $153 \pm 27 \mathrm{~min}$ (ESI, Fig. S27†). The magnetic heating of the maghemite nanoparticles leads to an accelerated CO release by a factor 2.3 through the increase in the surface temperature of the IONP, which affects the attached CORM (Fig. 3a).

We determined the AC effect only at the physiologically relevant temperature of $37{ }^{\circ} \mathrm{C}$. We have shown recently with a CORM-3@IONP analog that the CO-release is accelerated from

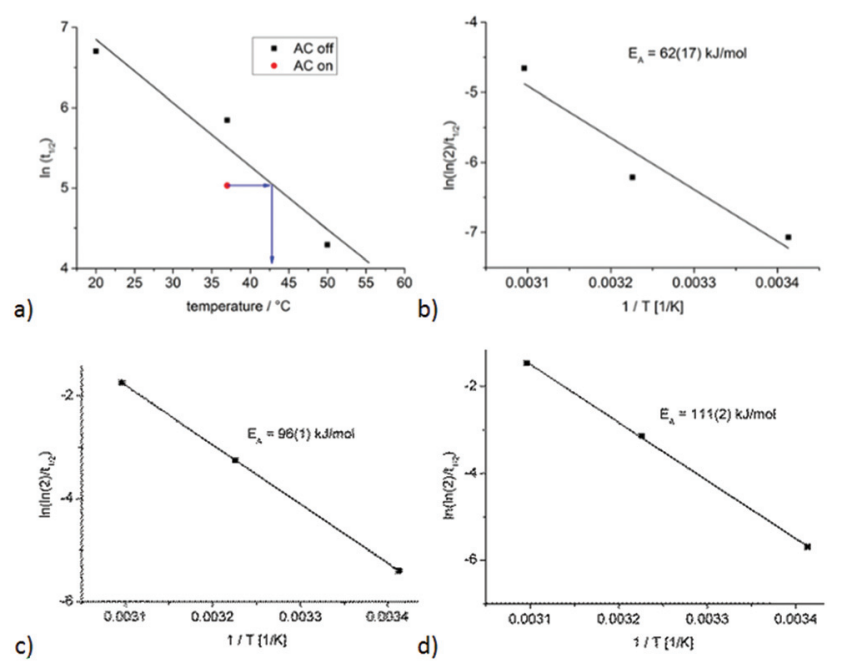

Fig. 3 (a) Correlation of $\ln \left(t_{1 / 2}\right)$ versus the temperature for 18 for $A C$ on and off to estimate the IONP surface temperature upon magnetic heating, thereby assuming a direct correlation between their half-life and temperature. The initial temperature position of the red dot ( $A C$ on) is the set solution temperature. The AC field then increases the temperature on the IONP surface as traced by the blue arrows. (b-d) Arrhenius plots for 18 (b), 11 (c) and 14 (d) of $\ln k=\ln \left(\ln (2) / t_{1 / 2}\right)$ versus $1 / T_{\text {Kelvin }}$ to determine the activation energy from the slope $\left(-E_{\mathrm{A}} / R, R=\right.$ $8.314 \mathrm{~J} \mathrm{~mol}^{-1} \mathrm{~K}^{-1}$ ) of the graph. a half-life of $890 \pm 70 \mathrm{~min}$ at $20^{\circ} \mathrm{C}, 172 \pm 27 \mathrm{~min}$ at $37^{\circ} \mathrm{C}$ and $45 \pm 7 \mathrm{~min}$ at $50{ }^{\circ} \mathrm{C}$ with an $\mathrm{AC}$ field to $155 \pm 18 \mathrm{~min}$ at $20^{\circ} \mathrm{C}$, $65 \pm 5 \mathrm{~min}$ at $37^{\circ} \mathrm{C}$ and $30 \pm 3 \mathrm{~min}$ at $50{ }^{\circ} \mathrm{C} .{ }^{42}$ Thus, the acceleration of $\mathrm{CO}$ release or lowering of the CORM half-life by the AC field will be even larger at $20{ }^{\circ} \mathrm{C}$.

IR spectroscopic measurements showed shifted carbonyl absorptions after the CO release of the composite material alginate@dextran@oximeCORM@IONP (18) from 2061 and $1991 \mathrm{~cm}^{-1}$ to 2071, 2015 and $1992 \mathrm{~cm}^{-1}$ (ESI, Fig. S28†). The complete disappearance of the carbonyl absorption bands could not be observed after the CO release studies with the myoglobin assay. Therefore, the release of both CO-ligands from oximeCORMs does not take place. For CORM-3 only one mol of $\mathrm{CO}$ can be released from $\left[\mathrm{Ru}(\mathrm{CO})_{3} \mathrm{Cl}\left(\mathrm{O}_{2} \mathrm{CCH}_{2} \mathrm{NH}_{2}\right)\right]$ in PBS buffered solution with myoglobin. After the release of one CO from CORM-3 an inactive form, termed iCORM is formed. The inactive iCORM-form of CORM-3 is not able to release further $\mathrm{CO}$ after the loss of one $\mathrm{CO} .^{16}$

The absolute amount of released CO was determined with the Lambert-Beer law and gave the formation of $0.2(1) \mathrm{mol}$ carbon monoxide per mol of $\mathrm{Ru}$ from alginate@dextran@ oximeCORM@IONP (18), 0.9(1) mol for 10, 0.8(1) mol for 11 and $0.9(1) \mathrm{mol}$ for 14 in the myoglobin assay (see eqn (1) in the ESI $\dagger$ ). The low CO amount per Ru in 18 results apparently from the CO loss during the synthesis. It is known from recent work that CORM-2 $\left(\left[\mathrm{Ru}(\mathrm{CO})_{3} \mathrm{Cl}_{2}\right]_{2}\right)$ will lose $1.8 \mathrm{CO}$ equivalents as $\mathrm{CO}_{2}$ in water within 24 h. ${ }^{37}$ In order to anchor 14 on maghemite nanoparticles (15) and coat with dextran to yield dextran@oximeCORM@IONP (17), the mixture had to be stirred in water for $3 \mathrm{~h}$. Inclusion of $\mathbf{1 7}$ in the alginate spheres, giving $\mathbf{1 8}$ added another $\sim 35$ min of water contact before the CO release measurements. Attempts to replace water by methanol in the formation of $\mathbf{1 7}$ led to agglomeration of the IONPs.

In our previous work on a CORM-3@IONP analog we realized that $\ln \left(t_{1 / 2}\right)$ shows a linear correlation with temperature and that the $\ln \left(t_{1 / 2}\right)$ values at $37^{\circ} \mathrm{C}$ (AC off) and $20^{\circ} \mathrm{C}$ (solution

Table 3 Cytotoxicity test of ruthenium CORMs and cisplatin against the human ovarian cancer cell line A2780, the human tongue cancer cell line Cal27 and the non-cancer cell line HEK293. The inhibition of cell growth is expressed as \% of untreated control ${ }^{a}$

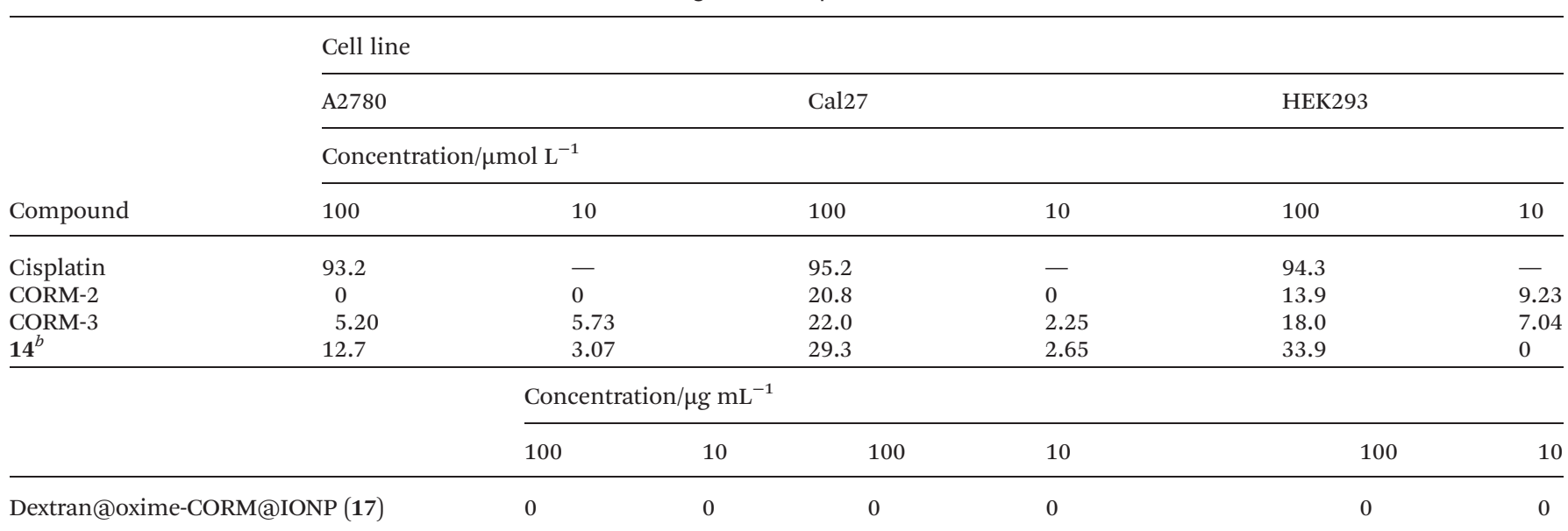

${ }^{a}$ Growth inhibition values are the average of experiments performed in triplicate. ${ }^{b}$ See Scheme 5 for the formula of the ethoxy-oximeCORM $\mathbf{1 4}$. 
temperature, AC on) were very close, with $\ln (172)=5.15$ and $\ln$ (155), respectively $=5.04$. From this, we deduced that the AC field at $20^{\circ} \mathrm{C}$ generates an IONP surface temperature of about $37^{\circ} \mathrm{C} .{ }^{42}$ The surface temperature of the IONP through the AC field was determined through a plot of $\ln \left(t_{1 / 2}\right)$ versus the temperature (Fig. 3a). Under the assumption that the half-life for the same material is only a function of temperature, then the $\ln \left(t_{1 / 2}\right)$ value reached under the AC magnetic field would correlate with an IONP surface temperature of $43{ }^{\circ} \mathrm{C}$ in the surrounding solution temperature of $37{ }^{\circ} \mathrm{C}$ (Fig. 3a). A determination of the activation energy $E_{\mathrm{A}}$ for the $\mathrm{CO}$ release from the alginate composite material 18 with an Arrhenius plot of $\ln \left(\ln (2) / t_{1 / 2}\right)$ versus $1 / T$ gives a value of $62(17) \mathrm{kJ} \mathrm{mol}^{-1}$ (AC off) (Fig. 3b). This activation energy (with its error margins) compares well to the value of $78 \mathrm{~kJ} \mathrm{~mol}^{-1}$ for the CO release from a CORM-3 analog embedded in a similar alginate@ dextran@CORM@IONP composite. ${ }^{42}$ Furthermore, we determined the activation energy for the CO release from 1a to 100(3) $\mathrm{kJ} \mathrm{mol}^{-1}$, from $2 \mathrm{a}$ to $96(12) \mathrm{kJ} \mathrm{mol}^{-1}$, from 10 to 99(1) $\mathrm{kJ} \mathrm{mol}^{-1}$, from 11 to $96(1) \mathrm{kJ} \mathrm{mol}^{-1}$ and from 14 to $111(2) \mathrm{kJ} \mathrm{mol}^{-1}$ (see ESI, Fig. S39†). The low correlation for 18 is due to its heterogeneous nature, whereas the CO release from compounds 1a, 2a, 10, 11 and 14 occurred in homogeneous solutions.

Toxicity tests of dextran@oximeCORM@IONP (17) against the three cell lines A2780, Cal27 and HEK293 showed no growth inhibition up to a concentration of 17 of $100 \mu \mathrm{g} \mathrm{mL}$ (see ESI, Fig. S35-S38†). The three reference compounds CORM-2, CORM-3, and 14 also showed no or low cytotoxic effects with $0-9.23 \%$ growth inhibition, respectively, at $10 \mu \mathrm{mol} \mathrm{L}{ }^{-1}$. A higher concentration of $100 \mu \mathrm{mol} \mathrm{L}{ }^{-1}$ showed moderate growth inhibition of $\mathbf{1 4}$ up to $33.9 \%$. For comparison, $100 \mu \mathrm{mol} \mathrm{L}{ }^{-1}$ cisplatin inhibited cell growth by $>93 \%$ (Table 3).

\section{Conclusions}

We have presented the formation of an oxime-based CORM covalently anchored on iron oxide nanoparticles and "solubilized" by a dextran coating. For this, we implemented a synthesis for the immobilization and backbone modification of oxime-based CORMs on iron oxide nanoparticles with a catechol anchor group. A dextran polymer coating with a molar mass of $500000 \mathrm{~g} \mathrm{~mol}^{-1}$ was applied to achieve good water "solubility" or rather a stable suspension of the modified iron oxide nanoparticles. For the measurement of the $\mathrm{CO}$ release with the myoglobin assay, the dark-colored CORMfunctionalized iron oxide nanoparticles had to be separated to allow for reliable UV/Vis absorption measurements. This in situ separation was achieved by incorporating the "soluble" dextran@oximeCORM@IONP into a calcium alginate sphere. The composite material alginate@dextran@oximeCORM@ IONP shows an extended half-life for $\mathrm{CO}$ release at $37^{\circ} \mathrm{C}$ of $346 \pm 83 \mathrm{~min}$ compared to the molecular oximeCORMs with the diol-protected catechol backbone 10 of $18 \pm \sim 3$ min and the unprotected catechol compound 14 of $16 \pm \sim 1$ min in the myoglobin assay. An alternating current magnetic field (31.7 $\mathrm{kA} \mathrm{m}^{-1}, 247 \mathrm{kHz}, 39.9$ mTesla) leads to a decrease of the halflife at $37{ }^{\circ} \mathrm{C}$ from $346 \pm 83$ (without AC field) to $153 \pm 27$ (with AC field).

\section{Experimental section}

All chemicals were purchased from Acros ${ }^{\circledR}$, Aldrich ${ }^{\circledR}$, VWR ${ }^{\circledR}$ and Fluka ${ }^{\circledR}$ and used as received. $\left[\mathrm{Ru}(\mathrm{CO})_{3} \mathrm{Cl}_{2}\right]_{2}(\mathbf{1 2})$ was synthesized according to literature procedures. ${ }^{48}$ Doubly-deionized (d.d.) water was obtained by Millipore Synergy with a conductivity of $0.05 \mu \mathrm{S} \mathrm{cm}^{-1}$.

${ }^{1} \mathrm{H}-\mathrm{NMR}$ spectra were recorded with a 300 or $600 \mathrm{MHz}$ Bruker FT-NMR Spectrometer Avance III. For measurements with $\mathrm{CDCl}_{3}$, tetramethylsilane (TMS) was used as an internal reference. Measurements in other solvents were referenced to the solvent signal (DMSO- $\mathrm{d}_{6} 2.50 \mathrm{ppm}$, acetone- $\mathrm{d}_{6} 2.04 \mathrm{ppm}$ ). All chemical shifts $\delta$ are given in ppm. Spectra were recorded at $300 \mathrm{~K} .{ }^{1} \mathrm{H}$ and ${ }^{13} \mathrm{C}$ NMR spectra are displayed in Fig. S1a-i in the $\mathrm{ESI} \dagger$ and illustrate the purity of the compounds.

Mass spectra were obtained with a HR-MS UHR-QTOF maXis 4G (Bruker Daltonics) or with an ESI Ion-Trap-APIMassenspektrometer Finnigan LCQ Deca (Thermo Quest). Ruthenium-containing fragments show the Ru-96, -98, -99, $-100,-101,-102$, and -104 isotope distribution patterns. The most intense peak of the isotope distribution is noted in the mass spectrometric assignments (based on ${ }^{102} \mathrm{Ru}$, mass 101.904 with $31.6 \%$ abundancy).

IR spectra were recorded on a Bruker Tensor 37 IR spectrometer as $\mathrm{KBr}$ discs or using an attenuated total reflectance (ATR) technique. Care was taken to keep the amount of the nanoparticle composites as low as possible by using only 1-2 mg composite material/30-50 $\mathrm{mg} \mathrm{KBr}$ because of the strong absorption of the dark nanoparticles. In order to see the relevant carbonyl bands the amount of substance needed to be higher than for pure compounds because of the low ruthenium carbonyl percentage in dextran@oximeCORM@IONP (17) and alginate@dextran@oximeCORM@ IONP (18). Attempted IR spectroscopic measurements of materials containing the black-colored nanoparticles in ATR mode gave only very small signal intensities. Only compounds without nanoparticles were measured by ATR. The integration time was set to 50 scans per wavenumber to obtain good quality spectra. The IR spectra are given in the ESI. $\dagger$

Dynamic light scattering measurements were carried out with a Malvern Zetasizer Nanoseries. For determination of the nanoparticles size distribution, a dispersion ("solution") with a minimum concentration of $1 \mathrm{mg} \mathrm{mL} \mathrm{m}^{-1}$ in doubly deionized water was prepared. Measurements at different concentrations of the dispersion yielded the same hydrodynamic diameter.

Alternating current (AC) field generator measurements were performed with a Hüttinger HF generator AXIO T5, equipped with a water-cooled copper induction coil. The system was 
operated at $247 \mathrm{kHz}$, with a magnetic field amplitude of 31.7 $\mathrm{kA} \mathrm{m}^{-1}$ and 39.9 mTesla.

UV/Vis-absorption spectra were collected on a Specord S 600 UV/Vis-spectrometer of Analytik Jena Co. This work was carried out under nitrogen or argon and with thermostated cuvettes.

Atomic absorption spectroscopy (AAS) measurements were performed with a Perkin Elmer AAS AAnalyst200 by MicroLab Kolbe, Höhenweg 17, D-45470 Mülheim.

Transmission electron microscopy (TEM) images were obtained with a Zeiss 902 TEM at the Center for Advanced Imaging (CAi) in the University of Düsseldorf. For the sample preparation about $1 \mathrm{mg}$ of the particles was dispersed by sonication and fast up-and-down pipetting using a $1 \mathrm{~mL}$ syringe in deionized water $(2 \mathrm{~mL})$. This dispersion was diluted $1: 10$ with deionized water to yield a very low concentration of the nanoparticles. One drop of this dispersion was placed on a holey thin film of amorphous carbon on a copper grid. After a contact time of $15 \mathrm{~min}$, the grid was floated on a water surface and held vertically to rinse of the solvent.

Column chromatography was performed using a Reveleris chromatograph from Grace.

\section{Toxicity tests}

Cisplatin was purchased from Sigma-Aldrich, and 3-(4,5-dimethylthiazol-2-yl)-2,5-diphenyltetrazolium bromide (MTT) from Serva (Germany). All other reagents were supplied by PAN Biotech (Germany).

Cell lines and cell culture. The human epithelial ovarian cancer cell line A2780 was obtained from the European Collection of Cell Cultures (ECACC, UK). The human tongue cell line Cal27 and the human embryonic kidney cell line HEK293 were obtained from the German Collection of Microorganisms and Cell Cultures (DSMZ, Germany). All cell lines were grown at $37{ }^{\circ} \mathrm{C}$ under a humidified atmosphere containing $5 \% \mathrm{CO}_{2}$ in RPMI 1640 (A2780) or DMEM (Cal27, HEK293) containing 10\% fetal calf serum, $120 \mathrm{IU} \mathrm{mL} \mathrm{m}^{-1}$ penicillin, and $120 \mu \mathrm{g} \mathrm{mL}^{-1}$ streptomycin. The cells were grown to $80 \%$ confluency before using them for the appropriate assays.

MTT cell viability assay. The rate of cell survival under the action of test compounds was evaluated by an improved MTT assay as previously described. ${ }^{49}$ In brief, A2780, Cal27 or HEK293 were seeded at a density of 5000 (A2780) or 2000 (Cal27, HEK293) cells per well in 96-well plates (Corning, Germany). After $24 \mathrm{~h}$, the cells were exposed to increased concentrations of test compounds. Incubation was ended after $72 \mathrm{~h}$ and the cell survival was determined by addition of MTT solution ( $5 \mathrm{mg} \mathrm{mL}^{-1}$ in phosphate buffered saline). The formazan precipitate was dissolved in DMSO (VWR, Germany). Absorbance was measured at $544 \mathrm{~nm}$ and $690 \mathrm{~nm}$ using a FLUOstar microplate reader (BMG LabTech, Germany).

\section{Synthesis}

Synthesis of dicarbonylchlorido(imidazole-2-carbaldehydeoxime)(methoxycarbonyl)ruthenium(II) (1a). Solutions of $100 \mathrm{mg}(0.20 \mathrm{mmol})$ of tricarbonyldichloridoruthenium(II)- dimer $\left[\mathrm{Ru}(\mathrm{CO})_{3} \mathrm{Cl}_{2}\right]_{2}(12)$ in $1.5 \mathrm{~mL}$ of methanol and $66 \mathrm{mg}$ (0.60 mmol) of imidazole-2-carbaldehydeoxime (synthesized according to ref. 50) in another $1.5 \mathrm{~mL}$ of methanol were combined and stirred for $5 \mathrm{~d}$ at $30{ }^{\circ} \mathrm{C}$. The solution became slightly red and a colorless solid was formed. The solid was separated by centrifugation and washed with cold methanol $(3 \times 2 \mathrm{~mL})$. Yield: $43 \mathrm{mg}\left(31 \%\right.$, lit.: $\left.41 \%{ }^{38}\right)$. IR (KBr): $\tilde{\nu}\left[\mathrm{cm}^{-1}\right]=2068,1990$. ${ }^{1} \mathrm{H}$ NMR $\left(300 \mathrm{MHz}, \mathrm{CD}_{3} \mathrm{OD}\right): \delta[\mathrm{ppm}]=8.43(\mathrm{~s}, 1 \mathrm{H}, \mathrm{C}-\mathrm{CH}=\mathrm{N})$, $7.42(\mathrm{~s}, 1 \mathrm{H}, \mathrm{imi}-\mathrm{CH}=\mathrm{CH}), 7.37(\mathrm{~s}, 1 \mathrm{H}, \mathrm{imi}-\mathrm{CH}=\mathrm{CH}), 3.36(\mathrm{~s}$, $3 \mathrm{H}, \mathrm{CH}_{3}$ ) (matching NMR in ref. 38).

Synthesis of dicarbonylchlorido(imidazol-2-carbaldehydeoxime)(ethoxycarbonyl)ruthenium(II) (2a). $100 \mathrm{mg}(0.20 \mathrm{mmol})$ of tricarbonyldichloridoruthenium(II)-dimer (12) were dissolved in $1.5 \mathrm{~mL}$ of ethanol. $66 \mathrm{mg}(0.60 \mathrm{mmol})$ of imidazole2-carbaldehydeoxime (synthesized according to ref. 50) was dissolved in another $1.5 \mathrm{~mL}$ of ethanol and subsequently mixed together. The vessel was closed and stirred for $5 \mathrm{~d}$ at $30{ }^{\circ} \mathrm{C}$. The solution became slightly red and a colorless solid was formed. The solid was centrifuged and washed with cold ethanol $(3 \times 2 \mathrm{~mL})$. Yield: $68 \mathrm{mg}\left(45 \%\right.$, lit.: $\left.53 \%{ }^{38}\right)$. IR $(\mathrm{KBr})$ : $\tilde{\nu}\left[\mathrm{cm}^{-1}\right]=2067,1994 .{ }^{1} \mathrm{H}$ NMR $\left(300 \mathrm{MHz}, \mathrm{CD}_{3} \mathrm{OD}\right): \delta[\mathrm{ppm}]=$ $8.43(\mathrm{~s}, 1 \mathrm{H}, \mathrm{C}-\mathrm{CH}=\mathrm{N}), 7.43(\mathrm{~s}, 1 \mathrm{H}, \mathrm{imi}-\mathrm{CH}=\mathrm{CH}), 7.37(\mathrm{~s}, 1 \mathrm{H}$, imi- $\mathrm{CH}=\mathrm{CH}$ ), $3.62\left(\mathrm{q},{ }^{3} \mathrm{~J}=7.1 \mathrm{~Hz}, 2 \mathrm{H}, \mathrm{CH}_{2}\right), 1.20\left(\mathrm{t},{ }^{3} \mathrm{~J}=\right.$ $7.1 \mathrm{~Hz}, 3 \mathrm{H}, \mathrm{CH}_{3}$ ) (matching NMR in ref. 38).

Synthesis of 1-(2-(3,4-dihydroxyphenyl)-2-oxoethyl)-1H-imidazole-2-carbaldehyde (5). A mixture of $2.0 \mathrm{~g}(7.0 \mathrm{mmol})$ of 7 in $200 \mathrm{~mL}$ of conc. acetic acid, $66 \mathrm{~mL}$ of d.d. water and $26 \mathrm{~mL}$ of $6 \mathrm{~mol} \mathrm{~L}^{-1}$ hydrochloric acid was stirred for $2 \mathrm{~h}$ at $100{ }^{\circ} \mathrm{C}$. After this the solvent was removed under vacuum, the residue was washed with $80 \mathrm{~mL}$ of d.d. water and the solid was removed by centrifugation. The aqueous phase was neutralized with sodium hydroxide, the precipitate was collected by centrifugation and dried under vacuum. Yield: $1.47 \mathrm{~g}$ (85\%). ESI-MS: $m / z=265.2\left[\mathrm{M}+\mathrm{H}+\mathrm{H}_{2} \mathrm{O}\right]^{+}, 247.2[\mathrm{M}+\mathrm{H}]^{+} .{ }^{1} \mathrm{H} \mathrm{NMR}$ $\left(300 \mathrm{MHz}\right.$, DMSO-d $\left.\mathrm{d}_{6}\right): \delta[\mathrm{ppm}]=9.64\left(\mathrm{~d},{ }^{5} J=0.8 \mathrm{~Hz}, 1 \mathrm{H}\right.$, $\mathrm{C}-\mathrm{CH}=\mathrm{O}), 7.56\left(\mathrm{t},{ }^{3 / 5} \mathrm{~J}=0.8,1 \mathrm{H}\right.$, imi-CH= $\left.\mathrm{CH}\right), 7.35\left(\mathrm{dd},{ }^{3} \mathrm{~J}=\right.$ $\left.8.4 \mathrm{~Hz},{ }^{4} J=2.2 \mathrm{~Hz}, 1 \mathrm{H}, \mathrm{C}_{\text {aryl }}-\mathrm{H}\right), 7.30\left(\mathrm{~d},{ }^{3} \mathrm{~J}=0.8 \mathrm{~Hz}, 1 \mathrm{H}\right.$, imi$\mathrm{CH}=\mathrm{CH}), 7.25\left(\mathrm{~d},{ }^{4} \mathrm{~J}=2.1 \mathrm{~Hz}, 1 \mathrm{H}, \mathrm{C}_{\text {aryl }}-\mathrm{H}\right), 6.65\left(\mathrm{~d},{ }^{3} J=8.3 \mathrm{~Hz}\right.$, $1 \mathrm{H}, \mathrm{C}_{\text {aryl }}-\mathrm{H}$ ), 5.88 (s, 2H, C(O)- $\left.\mathrm{CH}_{2}-\mathrm{NN}\right) .{ }^{13} \mathrm{C}-\mathrm{NMR}$ (see Fig. S1a $\dagger$ ) (75 MHz, DMSO-d $)_{6}: \delta[\mathrm{ppm}]=189.95(\mathrm{C}=\mathrm{O})$, $181.85(\mathrm{CH}=\mathrm{O}), 153.52$ (aryl- $\mathrm{COH}), 146.15$ (aryl- $\mathrm{COH}), 143.51$ $(\mathrm{N}-\mathrm{C}=\mathrm{N}), 130.82$ (aryl-C-CO), $128.72\left(\mathrm{C}_{\text {aryl }}-\mathrm{H}\right), 124.99$ (imi$\mathrm{CH}=\mathrm{CH}), \quad 121.52$ (imi- $\mathrm{CH}=\mathrm{CH}), \quad 115.35 \quad\left(\mathrm{C}_{\text {aryl }}-\mathrm{H}\right), \quad 114.32$ $\left(\mathrm{C}_{\text {aryl }}-\mathrm{H}\right), 53.39\left(\mathrm{CH}_{2}\right)$.

Synthesis of 2-chloro-1-(2,2-dimethylbenzo[d][1,3]dioxol-5-yl) ethanone (6). A mixture of $6.0 \mathrm{~g}(32.6 \mathrm{mmol})$ of 2-chloro-2,4dihydroxy-acetophenone with $0.95 \mathrm{~g}$ phosphorus pentoxide in $120 \mathrm{~mL}$ of dry toluene was stirred under nitrogen at $75^{\circ} \mathrm{C}$ and, every $20 \mathrm{~min}$ a portion of $0.55 \mathrm{~mL}$ acetone and every $30 \mathrm{~min}$ $0.85 \mathrm{~g}$ phosphorus pentoxide were added over a period of $4 \mathrm{~h}$. After adding $24 \mathrm{~mL}$ of aqueous $20 \%$ sodium hydroxide, the aqueous phase was removed by decantation and discarded. The organic phase was washed with d.d. water $(3 \times 60 \mathrm{~mL})$. The toluene solvent was removed and the solid was dried under vacuum. Yield: $6.6 \mathrm{~g}(87 \%) .{ }^{1} \mathrm{H}$ NMR (see Fig. S1b $\dagger$ ) $\left(300 \mathrm{MHz}\right.$, acetone- $\left.\mathrm{d}_{6}\right): \delta[\mathrm{ppm}]=7.64\left(\mathrm{dd},{ }^{3} \mathrm{~J}=8.2 \mathrm{~Hz},{ }^{4} \mathrm{~J}=1.8\right.$ 
$\left.\mathrm{Hz}, 1 \mathrm{H}, \mathrm{C}_{\mathrm{aryl}}-\mathrm{H}\right), 7.37$ (dd, ${ }^{4} J=1.8 \mathrm{~Hz},{ }^{5} \mathrm{~J}=0.4 \mathrm{~Hz}, 1 \mathrm{H}, \mathrm{C}_{\text {aryl }}-\mathrm{H}$ ), $6.90\left(\mathrm{dd},{ }^{3} J=8.2 \mathrm{~Hz},{ }^{5} J=0.4 \mathrm{~Hz}, 1 \mathrm{H}, \mathrm{C}_{\text {aryl }}-\mathrm{H}\right), 4.91(\mathrm{~s}, 2 \mathrm{H}$, $\left.\mathrm{CH}_{2}-\mathrm{Cl}\right), 1.71$ (s, 6H, $\left.\mathrm{CH}_{3}\right)$.

Synthesis of 1-(2-(2,2-dimethylbenzo[d][1,3]dioxol-5-yl)-2oxoethyl)-1H-imidazole-2-carbaldehyde (7). $5.0 \mathrm{~g}$ (22.1 $\mathrm{mmol})$ of 6, $2.34 \mathrm{~g}$ (22.1 mmol) $\mathrm{Na}_{2} \mathrm{CO}_{3}$ and $4.24 \mathrm{~g}$ (44.2 mmol) imidazole-2-carboxaldehyde (4) were dissolved in $200 \mathrm{~mL}$ of acetonitrile and stirred for $10 \mathrm{~d}$ at $60{ }^{\circ} \mathrm{C}$ under a dry atmosphere. The solid was removed by centrifugation and the supernatant solution was poured into $1 \mathrm{~L}$ of d.d. water. The formed solid was separated by centrifugation and dried under vacuum. The crude product was dissolved in $60 \mathrm{~mL}$ of ethyl acetate and purified using a Reveleris Chromatograph from Grace (4 runs with $120 \mathrm{~g}$ silica column, ethyl acetate $\left.40 \mathrm{~mL} \mathrm{~min}^{-1}\right)$. Yield: $2.5 \mathrm{~g}(40 \%) .{ }^{1} \mathrm{H}$ NMR (Fig. S1c $\dagger$ ) (300 MHz, acetone-d $\left.{ }_{6}\right): \delta$ $[\mathrm{ppm}]=9.67\left(\mathrm{~d},{ }^{5} J=0.9 \mathrm{~Hz}, 1 \mathrm{H}, \mathrm{C}-\mathrm{CH}=\mathrm{O}\right), 7.71\left(\mathrm{dd},{ }^{3} J=8.2\right.$ $\left.\mathrm{Hz},{ }^{4} J=1.8 \mathrm{~Hz}, 1 \mathrm{H}, \mathrm{C}_{\text {aryl }}-\mathrm{H}\right), 7.48\left(\mathrm{t},{ }^{3 / 5} \mathrm{~J}=0.9 \mathrm{~Hz}, 1 \mathrm{H}\right.$, imi$\mathrm{CH}=\mathrm{CH}), 7.40\left(\mathrm{~d},{ }^{4} \mathrm{~J}=1.8 \mathrm{~Hz}, 1 \mathrm{H}, \mathrm{C}_{\text {aryl }}-\mathrm{H}\right), 7.30\left(\mathrm{~d},{ }^{3} \mathrm{~J}=0.9 \mathrm{~Hz}\right.$, $1 \mathrm{H}$, imi- $\mathrm{CH}=\mathrm{CH}), 6.94\left(\mathrm{~d},{ }^{3} J=8.1 \mathrm{~Hz}, 1 \mathrm{H}, \mathrm{C}_{\text {aryl }}-\mathrm{H}\right), 5.99(\mathrm{~s}$, $2 \mathrm{H}, \mathrm{C}(\mathrm{O})-\mathrm{CH}_{2}-\mathrm{N}$ ), $1.72\left(\mathrm{~s}, 6 \mathrm{H}, \mathrm{CH}_{3}\right) \cdot{ }^{13} \mathrm{C} \mathrm{NMR}$ (Fig. $\mathrm{S} 1 \mathrm{~d} \dagger$ ) $\left(75 \mathrm{MHz}\right.$, acetone- $\left.\mathrm{d}_{6}\right): \delta[\mathrm{ppm}]=190.56(\mathrm{C}=\mathrm{O}), 182.61$ $(\mathrm{CH}=\mathrm{O}), 153.11$ (aryl- $\mathrm{COH}), 148.99$ (aryl-COH), $144.84(\mathrm{~N}-$ $\mathrm{C}=\mathrm{N}), 131.82$ (aryl-C-CO), $129.79\left(\mathrm{C}_{\text {aryl }}-\mathrm{H}\right), 129.02$ (imi$\mathrm{CH}=\mathrm{CH}), 124.87$ (imi- $\mathrm{CH}=\mathrm{CH}), 120.67\left(\mathrm{C}-\left(\mathrm{CH}_{3}\right)_{2}\right), 108.89$ $\left(\mathrm{C}_{\text {aryl }}-\mathrm{H}\right), 108.04\left(\mathrm{C}_{\text {aryl }}-\mathrm{H}\right), 54.33\left(\mathrm{CH}_{2}\right), 25.89\left(\mathrm{CH}_{3}\right)$.

Synthesis of $(E)-1-(2-(2,2-d i m e t h y l b e n z o[d][1,3]$ dioxol-5-yl)-2oxoethyl)- $1 \mathrm{H}$-imidazol-2-carbaldehyde-oxime (8). A mixture of $200 \mathrm{mg}(0.70 \mathrm{mmol})$ of 7 with $74 \mathrm{mg}(0.7 \mathrm{mmol})$ of sodium carbonate and $94 \mathrm{mg}(1.4 \mathrm{mmol})$ of hydroxyl ammonium chloride, $\left[\mathrm{NH}_{3} \mathrm{OH}\right] \mathrm{Cl}$ in $4 \mathrm{~mL}$ of d.d. water was stirred for $24 \mathrm{~h}$ at $70{ }^{\circ} \mathrm{C}$. The obtained solid was separated by centrifugation at $5{ }^{\circ} \mathrm{C}$, washed with ethyl acetate $(3 \times 5 \mathrm{~mL})$ and dried under vacuum. Yield: $158 \mathrm{mg}$ (75\%). ESI-MS: $m / z=302.1[\mathrm{M}+\mathrm{H}]^{+} .{ }^{1} \mathrm{H}$ NMR (Fig. S1 $\mathrm{e}^{\dagger}$ ) $\left(300 \mathrm{MHz}, \mathrm{DMSO}-\mathrm{d}_{6}\right): \delta[\mathrm{ppm}]=11.22(\mathrm{~s}, 1 \mathrm{H}$, NO-H), $7.97(\mathrm{~s}, 1 \mathrm{H}, \mathrm{C}-\mathrm{CH}=\mathrm{N}), 7.65\left(\mathrm{dd},{ }^{3} \mathrm{~J}=8.2 \mathrm{~Hz},{ }^{4} \mathrm{~J}=2.4\right.$ $\left.\mathrm{Hz}, 1 \mathrm{H}, \mathrm{C}_{\text {aryl }}-\mathrm{H}\right), 7.44\left(\mathrm{~d},{ }^{4} J=1.7 \mathrm{~Hz}, 1 \mathrm{H}, \mathrm{C}_{\text {aryl }}-\mathrm{H}\right), 7.24\left(\mathrm{~d},{ }^{3} J=\right.$ $0.9 \mathrm{~Hz}, 1 \mathrm{H}$, imi-CH=CH), $7.04\left(\mathrm{~d},{ }^{3} \mathrm{~J}=1 \mathrm{~Hz}, 1 \mathrm{H}\right.$, imi- $\left.\mathrm{CH}=\mathrm{CH}\right)$, $7.02\left(\mathrm{~d},{ }^{3} J=8.35 \mathrm{~Hz}, 1 \mathrm{H}, \mathrm{C}_{\text {aryl }}-\mathrm{H}\right), 5.86$ (s, 2H, C(O)- $\left.\mathrm{CH}_{2}-\mathrm{N}\right)$, $1.70\left(\mathrm{~s}, 6 \mathrm{H}, \mathrm{CH}_{3}\right)$.

Synthesis of 1-(2-(3,4-dihydroxyphenyl)-2-oxoethyl)-1H-imidazole-2-carbaldehyde-oxime (9). $300 \mathrm{mg}(1.22 \mathrm{mmol})$ of 5 , $95 \mathrm{mg}(1.22 \mathrm{mmol})$ of $\mathrm{Na}_{2} \mathrm{CO}_{3}$ and $169 \mathrm{mg}(2.44 \mathrm{mmol})$ of hydroxyl ammonium chloride were dissolved in $10 \mathrm{~mL}$ of d.d. water and stirred for $24 \mathrm{~h}$ at $70^{\circ} \mathrm{C}$. The solid was separated by centrifugation at $5{ }^{\circ} \mathrm{C}$, washed with d.d. water $(3 \times 5 \mathrm{~mL})$ and dried under vacuum. Yield: $151 \mathrm{mg}(47 \%)$. IR (KBr): $\tilde{\nu}\left[\mathrm{cm}^{-1}\right]=$ 1692, 1472. High-resolution, HR-ESI MS: $m / z=262.0822$, calc. for $[\mathrm{M}+\mathrm{H}]^{+} m / z=262.0823$, matching with the exact mass for the indicated fragment; the absence of other significant peaks (besides the isotope pattern) confirms the purity of compound 9 (see Fig. S4a $\dagger$ ). ${ }^{1} \mathrm{H}-\mathrm{NMR}$ (Fig. S1f $\dagger$ ) (600 MHz, DMSO-d ${ }_{6}$ ): $\delta[\mathrm{ppm}]=11.21(\mathrm{~s}, 1 \mathrm{H}, \mathrm{N}-\mathrm{OH}), 9.99(\mathrm{~s}, 1 \mathrm{H}, \mathrm{C}-\mathrm{OH}), 9.45(\mathrm{~s}, 1 \mathrm{H}$, $\mathrm{C}-\mathrm{OH}), 7.96(\mathrm{~s}, 1 \mathrm{H}, \mathrm{C}-\mathrm{CH}=\mathrm{N}), 7.44\left(\mathrm{dd},{ }^{3} \mathrm{~J}=8.27 \mathrm{~Hz},{ }^{4} J=\right.$ $\left.2.1 \mathrm{~Hz}, 1 \mathrm{H}, \mathrm{C}_{\text {aryl }}-\mathrm{H}\right), 7.37\left(\mathrm{~d},{ }^{4} J=2.1 \mathrm{~Hz}, 1 \mathrm{H}, \mathrm{C}_{\text {aryl }}-\mathrm{H}\right), 7.23$ (s br, $1 \mathrm{H}$, imi-CH= $\mathrm{CH}$ ), 7.03 (s br, $1 \mathrm{H}$, imi- $\mathrm{CH}=\mathrm{CH}), 6.87$ (d, $\left.{ }^{3} J=8.26, \mathrm{C}_{\text {aryl }}-\mathrm{H}\right), \quad 5.80\left(\mathrm{~s}, \quad 2 \mathrm{H}, \mathrm{C}(\mathrm{O})-\mathrm{CH}_{2}-\mathrm{N}\right) .{ }^{13} \mathrm{C}-\mathrm{NMR}$
(Fig. S1g $)$ (125 MHz, DMSO-d $\left.{ }_{6}\right): \delta[\mathrm{ppm}]=190.62(\mathrm{C}=\mathrm{O})$, 151.22 (aryl- $\mathrm{COH}), 145.37$ (aryl- $\mathrm{COH}), 141.44(\mathrm{CH}=\mathrm{NOH})$, $140.41(\mathrm{~s}, 1 \mathrm{C}, \mathrm{N}-\mathrm{C}=\mathrm{N}), 128.34$ (aryl-C-CO), $126.30\left(\mathrm{C}_{\text {aryl }}-\mathrm{H}\right)$, 124.77 (imi- $\mathrm{CH}=\mathrm{CH}), 121.14(\mathrm{imi}-\mathrm{CH}=\mathrm{CH}), 115.20\left(\mathrm{C}_{\text {aryl }}-\mathrm{H}\right)$, $114.69\left(\mathrm{C}_{\text {aryl }}-\mathrm{H}\right), 53.33\left(\mathrm{CH}_{2}\right)$.

Synthesis of $\left[\mathrm{Ru}\left(\eta^{2}-8\right)(\right.$ methoxycarbonyl $\left.)(\mathrm{CO})_{2} \mathrm{Cl}\right] \quad(10)$. $270 \mathrm{mg}(0.9 \mathrm{mmol})$ of 8 and $170 \mathrm{mg}(0.3 \mathrm{mmol})$ of $\left[\mathrm{Ru}(\mathrm{CO})_{3} \mathrm{Cl}_{2}\right]_{2} \quad(12)$ were separately dissolved in $2.5 \mathrm{~mL}$ of methanol, combined and stirred for $5 \mathrm{~d}$ at $30^{\circ} \mathrm{C}$ in a closed vessel. The solid was sedimented by centrifugation at $5{ }^{\circ} \mathrm{C}$, washed with cold methanol $(3 \times 5 \mathrm{~mL})$ and dried under vacuum. Yield: $249 \mathrm{mg}$ (50\%). IR (ATR): $\tilde{\nu}\left[\mathrm{cm}^{-1}\right]=2074 ; 1985$, IR $(\mathrm{KBr}): \tilde{\nu}\left[\mathrm{cm}^{-1}\right]=2075 ; 1989$. ESI-MS: $m / z=527.0[\mathrm{M}-$ $\left.\mathrm{OMe}^{-}-\mathrm{Cl}^{-}-\mathrm{H}^{+}+\mathrm{CH}_{3} \mathrm{CN}\right]^{+}, 499.1\left[\mathrm{M}-\mathrm{CO} / \mathrm{OMe}^{-}-\mathrm{Cl}^{-}-\mathrm{H}^{+}\right.$ $\left.+\mathrm{CH}_{3} \mathrm{CN}\right]^{+} \cdot{ }^{1} \mathrm{H}$ NMR (Fig. S1h $\dagger$ ) (300 MHz, acetone- $\left.\mathrm{d}_{6}\right): \delta$ $[\mathrm{ppm}]=8.75$ ("d" = 2s for different cis- and trans ligands, $1 \mathrm{H}$, $\mathrm{C}-\mathrm{CH}=\mathrm{N}), 7.72\left(\mathrm{dd},{ }^{3} \mathrm{~J}=8.2,1.8 \mathrm{~Hz}, 1 \mathrm{H}, \mathrm{C}_{\text {aryl }}-\mathrm{H}\right), 7.51-7.46$ (m, 2H, imi-CH=CH), $7.42\left(\mathrm{~d},{ }^{4} J=1.8 \mathrm{~Hz}, 1 \mathrm{H}, \mathrm{C}_{\text {aryl }}-\mathrm{H}\right), 6.97$ (d, $\left.{ }^{3} J=8.2 \mathrm{~Hz}, 1 \mathrm{H}, \mathrm{C}_{\text {aryl }}-\mathrm{H}\right), 6.05$ (s br, $\left.2 \mathrm{H}, \mathrm{C}(\mathrm{O})-\mathrm{CH}_{2}-\mathrm{N}\right), 3.75$ $\left(\mathrm{s}, 3 \mathrm{H}, \mathrm{COOCH}_{3}\right), 1.72\left(\mathrm{~s}, 6 \mathrm{H},\left(\mathrm{CH}_{3}\right)_{2}\right)$.

Synthesis of $\left[\mathrm{Ru}\left(\boldsymbol{\eta}^{2}-8\right)(\text { ethoxycarbonyl)(CO) })_{2} \mathbf{C l}\right](11) .250 \mathrm{mg}$ $(0.83 \mathrm{mmol})$ of 8 and $160 \mathrm{mg}(0.313 \mathrm{mmol})$ of $\left[\mathrm{Ru}(\mathrm{CO})_{3} \mathrm{Cl}_{2}\right]_{2}$ (12) were separately dissolved in $2.5 \mathrm{~mL}$ of ethanol, combined and stirred for $5 \mathrm{~d}$ at $30^{\circ} \mathrm{C}$ in a closed vessel. The solid was sedimented by centrifugation at $5{ }^{\circ} \mathrm{C}$, washed with cold ethanol $(3 \times 5 \mathrm{~mL})$ and dried under vacuum. Yield: $221 \mathrm{mg}$ (47\%). IR (ATR): $\tilde{\nu}\left[\mathrm{cm}^{-1}\right]=2059 ; 1986, \operatorname{IR}(\mathrm{KBr}): \tilde{\nu}\left[\mathrm{cm}^{-1}\right]=$ 2065, 1988. ESI-MS (Fig. S3a $\dagger$ ): $m / z=527.0\left[\mathrm{M}-\mathrm{OEt}^{-}-\mathrm{Cl}^{-}-\right.$ $\left.\mathrm{H}^{+}+\mathrm{CH}_{3} \mathrm{CN}\right]^{+}, 499.1\left[\mathrm{M}-\mathrm{CO} / \mathrm{OEt}^{-}-\mathrm{Cl}^{-}-\mathrm{H}^{+}+\mathrm{CH}_{3} \mathrm{CN}\right]^{+} \cdot{ }^{1} \mathrm{H}$ NMR (Fig. S1i†) $\left(300 \mathrm{MHz}\right.$, acetone- $\left.\mathrm{d}_{6}\right): \delta[\mathrm{ppm}]=8.73$ ("d" = 2s for different cis- and trans ligands, $1 \mathrm{H}, \mathrm{C}-\mathrm{CH}=\mathrm{N}$ ), 7.72 (dd, $\left.{ }^{3} J=8.2 \mathrm{~Hz},{ }^{4} J=1.8 \mathrm{~Hz}, 1 \mathrm{H}, \mathrm{C}_{\text {aryl }}-\mathrm{H}\right), 7.51-7.47(\mathrm{~m}, 2 \mathrm{H}$, imi$\mathrm{CH}=\mathrm{CH}), 7.42\left(\mathrm{~d},{ }^{4} \mathrm{~J}=1.8 \mathrm{~Hz}, 1 \mathrm{H}, \mathrm{C}_{\text {aryl }}-\mathrm{H}\right), 6.97\left(\mathrm{~d},{ }^{3} \mathrm{~J}=8.2 \mathrm{~Hz}\right.$, $\left.1 \mathrm{H}, \mathrm{C}_{\text {aryl }}-\mathrm{H}\right), 6.06\left(\mathrm{~s} \mathrm{br}, 2 \mathrm{H}, \mathrm{C}(\mathrm{O})-\mathrm{CH}_{2}-\mathrm{N}\right), 4.26\left(\mathrm{t},{ }^{3} \mathrm{~J}=8 \mathrm{~Hz}\right.$, $\left.2 \mathrm{H},-\mathrm{OCH}_{2}-\right), 1.72\left(\mathrm{~s}, 6 \mathrm{H}, \mathrm{C}\left(\mathrm{CH}_{3}\right)_{2}\right), 1.28\left(\mathrm{t},{ }^{3} \mathrm{~J}=7 \mathrm{~Hz}, 3 \mathrm{H}\right.$, $\left.-\mathrm{CH}_{3}\right)$.

Synthesis of $\left[\mathrm{Ru}\left(\boldsymbol{\eta}^{2}-9\right)(\text { methoxycarbonyl)(CO) })_{2} \mathbf{C l}\right](13) .50 \mathrm{mg}$ $(0.19 \mathrm{mmol})$ of 9 and $48 \mathrm{mg}(96 \mu \mathrm{mol})$ of $\left[\mathrm{Ru}(\mathrm{CO})_{3} \mathrm{Cl}_{2}\right]_{2}(\mathbf{1 2})$ were separately dissolved in $1 \mathrm{~mL}$ of methanol, combined and stirred for $5 \mathrm{~d}$ at $30^{\circ} \mathrm{C}$ in a closed vessel. The solvent was removed under vacuum and the solid was analysed as a crude product. Compound 13, which was detected by mass spectrometric analysis, did not precipitate in a concentrated or cold solution and we were not able to purify the crude product. Therefore, compound $\mathbf{1 4}$ which could be precipitated from the solution as a colorless product and purified with cold ethanol was used for the $\mathrm{CO}$ release experiments. Yield: $88.5 \mathrm{mg}$ (crude product). ESI-MS: $m / z=487.0\left[\mathrm{M}-\mathrm{OMe}^{-}-\mathrm{Cl}^{-}-\mathrm{H}^{+}+\right.$ $\left.\mathrm{CH}_{3} \mathrm{CN}\right]^{+}, 459.2\left[\mathrm{M}-\mathrm{CO} / \mathrm{OMe}^{-}-\mathrm{Cl}^{-}-\mathrm{H}^{+}+\mathrm{CH}_{3} \mathrm{CN}\right]^{+}$.

Synthesis of $\left[\mathrm{Ru}\left(\eta^{2}-9\right)\left(\right.\right.$ ethoxycarbonyl)(CO) $\left.{ }_{2} \mathrm{Cl}\right](14) .50 \mathrm{mg}$ $(0.19 \mathrm{mmol}) 9$ and $32 \mathrm{mg} 12(63 \mu \mathrm{mol})$ were separately dissolved in $1 \mathrm{~mL}$ ethanol, combined and stirred for $5 \mathrm{~d}$ at $30^{\circ} \mathrm{C}$ in a closed vessel. The solid was sedimented by centrifugation at $5{ }^{\circ} \mathrm{C}$, washed with cold ethanol $(3 \times 5 \mathrm{~mL})$ and dried under vacuum. Yield: $70 \mathrm{mg}$ (70\%). IR (KBr): $\tilde{\nu}\left[\mathrm{cm}^{-1}\right]=2064,1995$, 1678, 1478. ESI-MS (Fig. S3b $\dagger$ ): $m / z=487.0\left[\mathrm{M}-\mathrm{OEt}^{-}-\mathrm{Cl}^{-}-\right.$ 
$\left.\mathrm{H}^{+}+\mathrm{CH}_{3} \mathrm{CN}\right]^{+}, 459.1\left[\mathrm{M}-\mathrm{CO} / \mathrm{OEt}^{-}-\mathrm{Cl}^{-}-\mathrm{H}^{+}+\mathrm{CH}_{3} \mathrm{CN}\right]^{+}$. High-resolution, HR-ESI-MS: $m / z=486.9828\left[\mathrm{M}-\mathrm{OEt}^{-}-\mathrm{Cl}^{-}\right.$ $\left.-\mathrm{H}^{+}+\mathrm{CH}_{3} \mathrm{CN}\right]^{+}, 458.9877\left[\mathrm{M}-\mathrm{CO} / \mathrm{OEt}^{-}-\mathrm{Cl}^{-}-\mathrm{H}^{+}+\right.$ $\left.\mathrm{CH}_{3} \mathrm{CN}\right]^{+}, 419.9768\left[\mathrm{M}-\mathrm{CO} / \mathrm{OEt}^{-}-\mathrm{Cl}^{*}+\mathrm{H}\right]^{+}$, all matching with the calculated patterns for the indicated fragment masses (see Fig. S4b-d $\dagger$ ). ${ }^{1} \mathrm{H}$ NMR $\left(500 \mathrm{MHz}\right.$, acetone- $\left.\mathrm{d}_{6}\right): \delta[\mathrm{ppm}]=$ $8.70(\mathrm{~s}, 1 \mathrm{H}, \mathrm{C}-\mathrm{CH}=\mathrm{N}), 7.60-7.38\left(\mathrm{~m}, 4 \mathrm{H}, \mathrm{imi}-\mathrm{CH}=\mathrm{CH}, 2 \mathrm{C}_{\mathrm{aryl}^{-}}\right.$ $\mathrm{H}), 6.99\left(\mathrm{~d},{ }^{3} J=8.2,1 \mathrm{H}, \mathrm{C}_{\text {aryl }}-\mathrm{H}\right), 6.11-5.88\left(\mathrm{~m}, 2 \mathrm{H}, \mathrm{C}(\mathrm{O})-\mathrm{CH}_{2}-\right.$ $\mathrm{N}), 3.57\left(\mathrm{q},{ }^{3} \mathrm{~J}=6.5,2 \mathrm{H},-\mathrm{OCH}_{2}-\right), 1.12\left(\mathrm{t},{ }^{3} \mathrm{~J}=6.7,3 \mathrm{H},-\mathrm{CH}_{3}\right)$. Calcd for $\mathrm{C}_{17} \mathrm{H}_{16} \mathrm{ClN}_{3} \mathrm{O}_{8} \mathrm{Ru}\left(526.85 \mathrm{~g} \mathrm{~mol}^{-1}\right)$ : C 38.76, H 3.06, N 7.98, found: C 38.72, H 3.09, N 7.47\%.

Immobilization of 14 on maghemite nanoparticles (16). A suspension of $5 \mathrm{mg}$ of 14 in $2 \mathrm{~mL}$ of d.d. water was mixed with a few drops of $0.1 \mathrm{~mol} \mathrm{~L}^{-1}$ sodium hydroxide to form a clear solution. $30 \mathrm{mg}$ of maghemite nanoparticles (15) were added as an aqueous dispersion ( $3 \mathrm{~mL}, 10 \mathrm{mg} \mathrm{mL}^{-1}$ ) and the solution was stirred for $15 \mathrm{~min}$. To prevent agglomeration of the nanoparticles the combined solutions of both compounds were kept below $\mathrm{pH}$ 8. After neutralizing with hydrochloric acid the solution was combined with $100 \mathrm{~mL}$ acetone and the precipitated solid was removed by centrifugation. The solid was washed with ethanol $3 \times 5 \mathrm{~mL}$ and dried under vacuum. Yield: $27 \mathrm{mg}$, IR (KBr): $\tilde{\nu}\left[\mathrm{cm}^{-1}\right]=2038,1916,1633,1487$.

Immobilization of 14 on maghemite nanoparticles in dextran (17). A suspension of $5 \mathrm{mg}$ of 14 in $2 \mathrm{~mL}$ of d.d. water was mixed with a few drops of $0.1 \mathrm{~mol} \mathrm{~L}^{-1}$ sodium hydroxide to form a clear solution. $30 \mathrm{mg}$ of maghemite nanoparticles (15) were added as an aqueous dispersion ( $3 \mathrm{~mL}, 10 \mathrm{mg} \mathrm{mL}^{-1}$ ) and the solution was stirred for $15 \mathrm{~min}$. Separately $60 \mathrm{mg}$ dextran $\left(M=500000 \mathrm{~g} \mathrm{~mol}^{-1}\right)$ was dissolved in $5 \mathrm{~mL}$ of d.d. water, combined with the above solution and stirred for $3 \mathrm{~h}$. After neutralizing with hydrochloric acid, $100 \mathrm{~mL}$ of acetone were added and the formed solid removed by centrifugation. The solid was washed with ethanol $3 \times 5 \mathrm{~mL}$ and the brown solid, now called composite material dextran@oximeCORM@ IONP (17) was dried under vacuum and stored for several weeks. Yield: $69 \mathrm{mg}, \mathrm{IR}(\mathrm{KBr}): \tilde{\nu}\left[\mathrm{cm}^{-1}\right]=$ 2064, 1995, 1961.

Embedding of 17 into alginate spheres (18). $10 \mathrm{mg}$ of 17 were dissolved in $0.5 \mathrm{~mL}$ MOPS buffer ( $\mathrm{pH}$ 7.4). Mixing of $0.5 \mathrm{~mL}$ of this solution with $0.5 \mathrm{~mL}$ alginate solution $(50 \mathrm{mg}$ sodium alginate in $10 \mathrm{~mL}$ d.d. water) leads to a viscous solution which was added dropwise (by B-Braun, Sterican syringe with a $0.60 \times 80 \mathrm{~mm} \mathrm{BL} / \mathrm{LB}$ needle) into a calcium chloride solution $\left(2 \mathrm{~g} \mathrm{CaCl}_{2} \cdot 6 \mathrm{H}_{2} \mathrm{O}\right.$ in $60 \mathrm{~mL}$ of d.d. water). The resulting spheres were left to stand for $30 \mathrm{~min}$ in the calcium chloride solution to form a fully cross-linked network of the alginate. Then the formed spheres were washed three times each with $10 \mathrm{~mL}$ of MOPS buffer and used directly for kinetic CO release experiments with the myoglobin assay.

\section{CO detection}

MOPS buffer 0.1 mol L ${ }^{-1}$ pH 7.4. $2.09 \mathrm{~g}$ (0.01 mol) of 3-(Nmorpholino)propanesulfonic acid (MOPS) were dissolved in $75 \mathrm{~mL}$ of d.d. water. Subsequently, the $\mathrm{pH}$ was adjusted to 7.4 using $\mathrm{NaOH}$ and water was added to reach a final volume of $100 \mathrm{~mL}$.
Myoglobin assay with molecular, soluble oxime-based CORMs. Myoglobin from equine skeletal muscle $(6.3 \mathrm{mg})$ was dissolved in $5 \mathrm{~mL} 3$-( $N$-morpholino)propanesulfonic acid buffer ( $\mathrm{pH} 7.4 ; 0.1 \mathrm{~mol} \mathrm{~L}^{-1}$ ) and deoxygenated for $10 \mathrm{~min}$ with nitrogen to yield a myoglobin solution $\left(66 \mu \mathrm{mol} \mathrm{L} \mathrm{L}^{-1}\right)$. Solid sodium dithionite was added ( $5 \mathrm{mg}$ ) to fully reduce the myoglobin to the $\mathrm{Fe}(\mathrm{II})$ state and the solution was deoxygenated with nitrogen for an additional $10 \mathrm{~min}$. To receive a $10 \mathrm{mmol}$ $\mathrm{L}^{-1}$ solution of the CORM, $1 \mathrm{mg}$ of the compound was dissolved in a corresponding amount of dimethylsulfoxide. A thermostable quartz-cell was filled with $1.5 \mathrm{~mL}$ myoglobin solution and $6 \mu \mathrm{L}$ of the CORM-solution and sealed with a Teflon plug to start the measurement immediately.

Myoglobin assay with alginate@dextran@oximeCORM@ IONP. A thermostable quartz-cell was filled with $1.3 \mathrm{~mL}$ MOPS buffer solution, 15 spheres of alginate@dextran@oximeCORM@IONP (18), $200 \mu \mathrm{L}$ of the above myoglobin/MOPS/ $\mathrm{Na}_{2} \mathrm{~S}_{2} \mathrm{O}_{3}$ solution and sealed with a Teflon plug to start the UV/Vis measurement immediately.

CO release in alternating current (AC) field. Measurements were performed with a Hüttinger HF generator AXIO T5, equipped with a water-cooled copper induction coil. The system was operated at $247 \mathrm{kHz}$, with a magnetic field amplitude of $31.7 \mathrm{kA} \mathrm{m}^{-1}$ and 39.9 mTesla. The thermostated quartz-cell was placed inside the copper induction coil (see Fig. S40 in the ESI $\dagger$ ). To keep the alginate spheres on the bottom of the UV-cell, a small permanent magnet was placed under the quartz-cell. In order to keep the conditions reproducible, this permanent magnet was used during every measurement, even without alginate.

\section{Acknowledgements}

We thank Dr Juri Barthel and the Ernst Ruska-Centre (ER-C) for Microscopy and Spectroscopy with Electrons, the Jülich Research Centre and the RWTH Aachen University, 52425 Jülich (Germany) for help and access to the HR-TEM facilities. Dr Peter Tommes is thanked for collecting the HR-ESI mass spectra.

\section{Notes and references}

1 B. J. Haldane, Biochem. J., 1927, 21, 1068-1075.

2 L. D. Prockop and R. I. Chichkova, J. Neurol. Sci., 2007, 262, 122-130.

3 T. R. Johnson, B. E. Mann, J. E. Clark, R. Foresti, C. J. Green and R. Motterlini, Angew. Chem., Int. Ed., 2003, 42, 3722-3729.

4 A. W. Carpenter and M. H. Schoenfisch, Chem. Soc. Rev., 2012, 41, 3742-3752.

5 D. S. Bredt and S. H. Snyder, Annu. Rev. Biochem., 1994, 63, 175-195.

6 B. E. Mann and R. Motterlini, Chem. Commun., 2007, 41974208. 
7 R. Tenhunen, H. S. Marver and R. Schmid, Proc. Natl. Acad. Sci. U. S. A., 1968, 61, 748-755.

8 D. Boehning and S. H. Snyder, Science, 2002, 298, 23392340.

9 R. Motterlini and L. E. Otterbein, Nature, 2010, 9, 728-743.

10 B. E. Mann, Organometallics, 2012, 31, 5728-5735.

11 R. Motterlini and L. E. Otterbein, Nat. Rev. Drug Discovery, 2010, 9, 728-743.

12 R. Foresti and R. Motterlini, Curr. Drug Targets, 2010, 11, 1595-1604.

13 M. Patra, M. Wenzel, P. Prochnow, V. Pierroz, G. Gasser, J. E. Bandow and N. Metzler-Nolte, Chem. Sci., 2015, 6, 214-224.

14 R. Motterlini, J. E. Clark, R. Foresti, P. Sarathchandra, B. E. Mann and C. J. Green, Circ. Res., 2002, 90, 17-24.

15 R. Motterlini, B. E. Mann, T. R. Johnson, J. E. Clark, R. Foresti and C. J. Green, Curr. Pharm. Des., 2003, 9, 25252539.

16 J. E. Clark, P. Naughton, S. Shurey, C. J. Green, T. R. Johnson, B. E. Mann, R. Foresti and R. Motterlini, Circ. Res., 2003, 93, 2-8.

17 R. Alberto and R. Motterlini, Dalton Trans., 2007, 16511660.

18 R. Motterlini, B. E. Mann and R. Foresti, Expert Opin. Invest. Drugs, 2005, 14, 1305-1318.

19 S. McLean, B. E. Mann and R. K. Poole, Anal. Biochem., 2012, 427, 36-40.

20 T. R. Johnson, B. E. Mann, I. P. Teasdale, H. Adams, R. Foresti and C. J. Green, Dalton Trans., 2007, 1500-1508.

21 T. Santos-Silva, A. Mukhopadhyay, J. D. Seixas, G. J. L. Bernandes, C. C. Romao and M. J. Romao, J. Am. Chem. Soc., 2011, 133, 1192-1195.

22 T. Pitchumony, B. Spingler, R. Motterlini and R. Alberto, Chimia, 2009, 62, 277-279.

23 R. Motterlini, P. Sawle, J. Hammad, S. Bains, R. Alberto, R. Foresti and C. J. Green, FASEB J., 2005, 19, 284-286.

24 N. E. Brückmann, M. Wahl, G. J. Reiß, M. Kohns, W. Wätjen and P. C. Kunz, Eur. J. Inorg. Chem., 2011, 45714577.

25 W. Huber, R. Linder, J. Niesel, U. Schatzschneider, B. Spingler and P. C. Kunz, Eur. J. Inorg. Chem., 2012, 31403146.

26 S. Romanski, B. Kraus, U. Schatzschneider, J. M. Neudörfl, S. Amslinger and H. G. Schmalz, Angew. Chem., Int. Ed., 2011, 50, 2392-22396.

27 N. S. Sitnikov, Y. Li, D. Zhang, B. Yard and H.-G. Schmalz, Angew. Chem., Int. Ed., 2015, 54, 12314-12318.

28 M. Ma, H. Noei, B. Mienert, J. Niesel, E. Bill and M. Muhler, Chem. - Eur. J., 2013, 19, 6785-6790.
29 G. Dördelmann, T. Meinhardt, T. Sowik, A. Krüger and U. Schatzschneider, Chem. Commun., 2012, 48, 11528-11530. 30 A. Ruggi and F. Zobi, Dalton Trans., 2015, 44, 10928-10931. 31 C. Bohlender, S. Glaeser, M. Klein, J. Weisser, S. Thein, U. Neugebauer, J. Popp, R. Wyrwa and A. J. Schiller, J. Mater. Chem. B, 2014, 2, 1454-1463.

32 U. Schatzschneider, Br. J. Pharmacol., 2015, 172, 16381650.

33 Y. Matsumura and H. Maeda, Cancer Res., 1986, 46, 63876392.

34 H. Maeda, J. Wu, T. Sawa, Y. Matsumura and K. Hori, J. Controlled Release, 2000, 65, 271-284.

35 L. D. D'Andrea, A. Romanelli, R. Di Stasi and C. Pedone, Dalton Trans., 2010, 39, 7625-7636.

36 E. Neuse, Met.-Based Drugs, 2008, 1-19.

37 J. D. Seixas, F. A. Marino, A. Mukhopadhyay, A. C. Coelho, P. M. Reis, L. F. Veiros, A. R. Marques, N. Penacho, A. M. L. Goncalves, M. J. Romao, G. J. L. Bernardes, T. Santos-Silva and C. C. Romao, Dalton Trans., 2015, 44, 5058-5075.

38 L. Oresmaa, H. Tarvainen, K. Machal and M. Haukka, Dalton Trans., 2012, 41, 11170-11175.

39 P. C. Kunz, H. Meyer, J. Barthel, S. Sollazzo, A. M. Schmidt and C. Janiak, Chem. Commun., 2013, 49, 4896-4898.

40 B. F. G. Johnson and J. S. McIndoe, Coord. Chem. Rev., 2000, 200-202, 901-932.

41 G. A. van Ewijk, G. J. Vroege and A. P. J. Philip, J. Magn. Magn. Mater., 1999, 201, 31-33.

42 H. Meyer, F. Winkler, P. Kunz, A. M. Schmidt, A. Hamacher, M. U. Kassack and C. Janiak, Inorg. Chem., 2015, 54(23), 11236-11246.

43 M. Klein, U. Neugebauer, A. Gheisari, A. Malassa, T. M. Jazzazi, F. Froehlich, M. Westerhausen, M. Schmitt and J. Popp, J. Phys. Chem. A, 2014, 118, 5381-5390.

44 L. Yuan, W. Y. Lin, L. Tan, K. B. Zheng and W. M. Huang, Angew. Chem., Int. Ed., 2013, 52, 1628-1630.

45 B. W. Michel, A. R. Lippert and C. J. Chang, J. Am. Chem. Soc., 2012, 134, 15668-15671.

46 H. J. Vreman and D. K. Stevenson, Anal. Biochem., 1988, 168, 31-81.

47 M. Balazy and H. Jiang, Acta Haematol., 2000, 103, 78-83.

48 A. Mantovani and S. Cenini, Inorg. Synth., 1976, 16, 51-53.

49 L. Marek, A. Hamacher, F. K. Hansen, K. Kuna, H. Gohlke, M. U. Kassack and T. Kurz, J. Med. Chem., 2013, 56, 427436.

50 L. Oresmaa, H. Kotikoski, M. Haukka, J. Salminen, O. Oksala, E. Pohjala, E. Moilanen, H. Vapaatalo, P. Vainiotalo and P. Aulaskari, J. Med. Chem., 2005, 48, 4231-4236. 